\title{
O Contributo de Sines na Eclosão de um Cluster Regional
}

Paulo Moreira

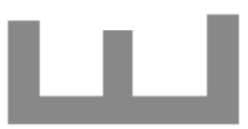

2013

R_2013/02

\section{RELATÓRIO}

REPORT

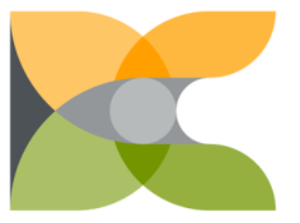

DINAMIP'CET

CENTRO DE ESTUDOS SOBRE A MUDANÇA SOCIOECONÓMICA E O TERRITÓRIO ISCTE IUL

FCT Fundação para a Ciência e a Tecnologia 


\title{
DINAMIP'CET
}

CENTRO DE ESTUDOS SOBRE A MUDANCA

ISCTE-IUL

\section{O Contributo de Sines na Eclosão de um}

Cluster Regional

\author{
Paulo Moreira*
}

R_2013/02

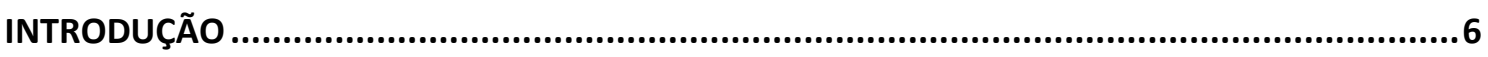

1. O PORTO DE SINES: PASSADO, PRESENTE E FUTURO ...........................................

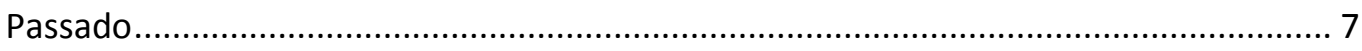

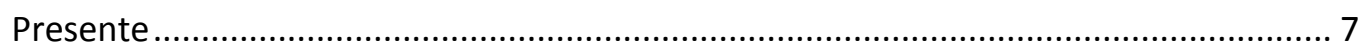

A cadeia marítima e a macroestrutura portuária …………......................................... 9

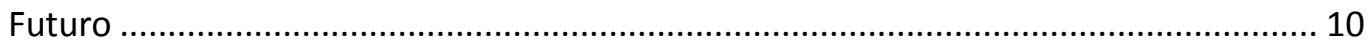

As linhas de serviço, a escolha dos portos e o conceito de centralidade ...................... 11

Competição inter-portuária; transhipment, hubs e gateways ........................................ 13

Competitividade e novos fluxos de comércio ............................................................. 14

Competição intra-portuária; os diversos agentes ...................................................... 16

Eficiência, produtividade e fiabilidade .................................................................... 17

A medida do desempenho portuário: eficiência ou eficácia? ......................................... 18

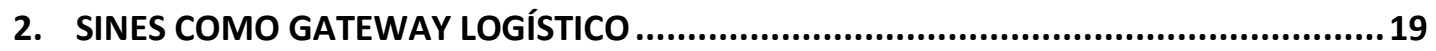

A ZILS (Zona Industrial e Logística de Sines) ............................................................... 19

Corredores de transportes e redes de distribuição ...................................................... 20

Delimitação da fronteira (estrutura espacial) ............................................................... 21

3. ANÁLISES QUANTITATIVAS: COEFICIENTES DE GINI E DE LOCALIZAÇÃO .....................22

Índice de Dependência de Cargas: o Coeficiente de Gini................................................ 22

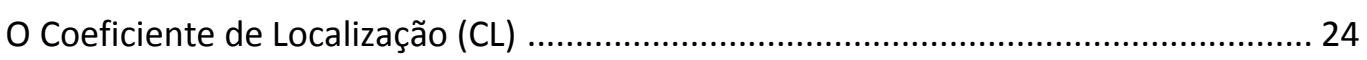

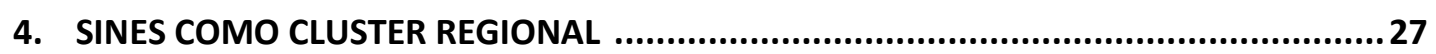

Economia e Desenvolvimento Regional .................................................................... 27

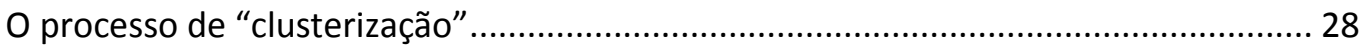

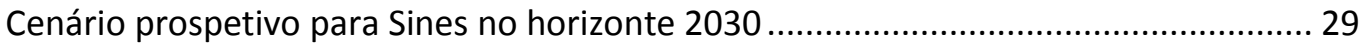

O alargamento do canal do Panamá: que resultados para Sines? ................................ 31

Considerações finais para Sines no horizonte 2030 ................................................... 32

DINÂMIA'CET - IUL, Centro de Estudos sobre a Mudança Socioeconómica e o Território

ISCTE-IUL - Av. das Forças Armadas, 1649-026 Lisboa, PORTUGAL

Tel. 210464031 - Extensão 293100 E-mail: dinamia@iscte.pt www.dinamiacet.iscte.pt 
5. RELATÓRIO FINAL - VISÃO ESTRATÉGICA E GLOBAL; UMA SÍNTESE POSSÍVEL ..........33

O posicionamento geográfico e a cadeia marítima ...................................................... 33

A natureza do porto de Sines e a competição direta ..................................................... 34

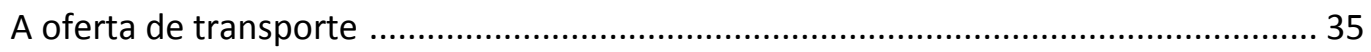

Sines como cluster regional: potencialidades e desafios ............................................ 37

Os "novos" players: o Brasil, o Mercosul e a China ......................................................... 39

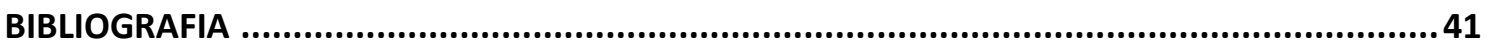

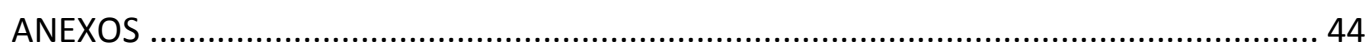

* Metropolitano de Lisboa, E.P.E. 


\title{
O Contributo de Sines na Eclosão de um
}

\section{Cluster Regional ${ }^{\mathbf{1}}$}

\section{Resumo}

O desenho daquilo que é traçado neste artigo não se confina ao estudo do porto de Sines numa lógica de pura gestão portuária, nem tão só à observação decomposta dos fluxos originados pelo chamado complexo industrial, dado que até ao presente, a história económica se encarregou de proceder a essa análise anatómica estrutural. Aquilo que se preconiza extravasa o mero circunstancialismo ou o somatório das partes e ambiciona olhar de modo multidimensional para Sines como um sistema aberto, caracterizado pela forma como as partes se organizam e como em conjunto podem contribuir para a revitalização económica, desenvolvimento sustentável e coesão social de toda uma parcela considerável do território nacional. Por outras palavras, assume-se a possibilidade da ocorrência de um cluster regional suportado nas redes mundiais da cadeia marítima.

Palavras-chave: Sines; cadeia marítima; gateway logístivo; cluster marítimo.

\begin{abstract}
The design of what is outlined in this paper is not confined to the study of the port of Sines in a logic of pure port management, not even only as the decomposed observation of flows originated by the so-called industrial complex, since until now, the economic history was charged of such anatomical structural analysis. What is called for is beyond the mere circumstances prevailing or the sum of the parts and aims to look Sines in a multidimensional way as an open system, characterized by how parts are organized and how together they can contribute to economic revitalization, sustainable development and social cohesion of a considerable portion of the national territory. In other words, we assume the possibility of the occurrence of a regional cluster supported on the global networks of the maritime chain.
\end{abstract}

Keywords: Sines; maritime chain; logistic gateway; maritime clusters.

\footnotetext{
${ }^{1}$ Este artigo foi elaborado tendo como suporte as conclusões retiradas da Tese de Mestrado em Economia Portuguesa e Integração Internacional, da autoria do autor e publicamente defendida em 4 de Outubro de 2012 no ISCTE-Business School. A Tese, com o título "A Análise De Sines Como Ativo Geoestratégico Nacional: Um Cluster Suportado Nas Redes Marítimas Mundiais, está disponível através do seguinte link: http://www.adfersit.pt/div tematica/dt201201.html
} 


\section{Sumário Executivo}

No atual estado da economia nacional em que o setor exportador é alvo de redobrada atenção como forma de diminuir o défice externo e o endividamento, em que se valorizam empresas cada vez mais competitivas e inovadoras, tal desígnio passa necessariamente por identificar quais (as empresas), como (lograr tal objetivo) e onde (se localizam). Isso é parte do contributo que se propõe oferecer ao longo deste documento, pretendendo-se identificar o caminho a prosseguir e propor a forma, para a discussão de Sines como um cluster constituído por empresas capazes de incorporar alto valor transacionável. Agora que reemerge na análise económica, a importância da "economia do mar e da procura por novos mercados de exportação, a opção pelo mar surge como uma inevitabilidade e como um desafio à adoção de uma política, global, para um setor que se apresenta como estratégico. Neste sentido, Sines configura-se como um ativo fundamental no contexto económico nacional decorrente do processo de globalização, de tal forma que, parafraseando a APS: "se o porto de Sines parasse, parava o país".

O destino económico de Sines e talvez mesmo de todo o Sul do país, está na verdade ligado à dinâmica do seu porto devendo este produzir forças centrífugas que estimulem, por efeito de arrastamento, os benefícios para lá da fronteira natural contrariando o nível de desconexão que possa vir a existir, principalmente numa região em que o litoral continua a ser a principal zona de interface. $\mathrm{O}$ acesso ao interior será certamente melhorado, o que implica que grande parte das atividades económicas ficarão localizadas mais para o interior e não, como convencionalmente tem sido o caso, nas proximidades dos seus terminais portuários. Com o acréscimo da influência do porto sobre o tecido socioeconómico regional, a fase que se anuncia será a de regionalização portuária do hinterland, processo que descreve o alargamento da importância da atividade marítimo-portuária ao seu hinterland principal. De acordo com este modelo (Notteboom e Rodrigue, 2005), a regionalização expande a atividade portuária através da adoção de várias estratégias, ligando-a de modo mais forte aos centros logísticos de distribuição de cargas no inland, o que aumenta a escala geográfica da atividade portuária para lá do perímetro do porto.

Esta nova condição e novo protagonismo acrescentam ao porto uma dimensão superior em termos geoestratégicos o que pressupõe falar das infraestruturas portuárias, da cadeia logística e dos modos de transporte associados. É pois inserido no âmbito da geoestratégia dos espaços económicos e das redes mundiais da cadeia marítima, entendendo-se por cadeia marítima, o mercado marítimo, portuário e logístico, que Sines deve ser colocado em análise, no pressuposto que as sinergias entre as partes contam mais que a sua soma individual.

Com o advento do alargamento do Canal do Panamá e perante um possível incremento das rotas marítimas trans-Atlântico por essa via, convirá antecipar qual o potencial em termos de atração de fluxos de carga para o porto de Sines, sem que este se transforme num simples hub intermédio de transhipment.

DINÂMIA'CET - IUL, Centro de Estudos sobre a Mudança Socioeconómica e o Território 
Um cluster regional suportado na economia do mar segundo a definição da CE, "consagra-se ao desenvolvimento da economia marítima através da inovação e da aproximação entre investigação, formação e a indústria. Acompanham projetos de investigação, favorecem o acesso das PME a novos mercados e inscrevem-se assim plenamente nos objetivos da estratégia de Lisboa - a qual atribui grande importância às políticas de inovação"2.

A inovação constitui uma necessidade no domínio marítimo (e nacional) e fornece a capacidade embrionária na gestação de um cluster regional desta natureza, dando especial atenção aos sectores da construção naval e da logística, da exploração dos recursos energéticos e biológicos marinhos, da aposta nas energias renováveis produzidas nomeadamente pelas correntes, pelas ondas e pelas marés, ao desenvolvimento de novos medicamentos provenientes da biodiversidade marinha, à prevenção de riscos, da segurança, da vigilância e da luta contra os efeitos das alterações climáticas e ainda ao desenvolvimento de um turismo sustentável que se integre na proteção do litoral ${ }^{3}$. Convém olhar para projetos da mesma ordem de importância estratégica criados na Finlândia, onde se desenvolvem competências industriais transversais que vão da área da nanotecnologia à tecnologia de produção de papel, passando pela investigação em inteligência artificial e pela pesquisa em energias alternativas ${ }^{4}$

No seguimento desta linha programática, Sines deve ser visto simultaneamente como plataforma geoestratégica, no que respeita à atuação direta da autoridade portuária do poder delegado pelo Governo da Nação e como ativo geoeconómico, segundo o primado da política global nacional.

\footnotetext{
2 In, http://ec.europa.eu/regional policy/sources/docgener/panorama/pdf/mag23/mag23 pt.pdf

${ }^{3}$ Vidé, http://ec.europa.eu/regional policy/sources/docgener/panorama/pdf/mag23/mag23 pt.pdf

${ }^{4}$ Por exemplo: http://www.oske.net/en/centres of expertise/satakunta/, este site dá-nos a conhecer a realidade do cluster marítimo de Satakunta
} 


\section{INTRODUÇÃO}

O conteúdo deste artigo apresenta-se estruturado da seguinte forma: na Seção 1 apresenta-se uma visão geral abrangente sobre o porto de Sines como ativo estratégico nacional. Analisa-se a macroestrutura como interface marítimo-terrestre e enunciam-se alguns princípios cruciais para a sua sobrevivência na guerra que se verifica em termos de atração de cargas: competitividade e centralidade. Esta Seção é dedicada igualmente ao estudo da importância do desempenho portuário medido em termos de eficiência (produtividade) e de eficácia (fidelização), cujo foco seja centrado nos clientes do porto. Neste contexto, surge a preocupação de elevar o desempenho de Sines para o efetivo controlo de gestão e a consequente reorientação estratégica, visando aumentar a competitividade.

Na Seção 2 lança-se um olhar sobre Sines como plataforma logística (gateway logístico)e efeitos multiplicadores sobre o tecido socioeconómico regional. Deste modo, às redes ferroviárias de transporte de mercadorias é-lhes atribuída uma importância fundamental no quadro da continuidade da cadeia de abastecimentos. É neste âmbito que se procede à análise da importância da adoção urgente da bitola europeia e da ligação direta à região de Madrid de modo que Sines não fique reduzido a um simples ramal de ligação a Espanha. Sobreleva portanto a interconectividade, algo que se constitui como a "espinha dorsal" do processo de regionalização da atividade portuária.

A Seção 3 dedica-se aos estudos quantitativos. Neste aspeto foram efetuadas duas análises: a análise do grau de especialização/diversificação através do cálculo de um índice e da sua relação em termos de assimetrias - Coeficiente de Gini aplicado ao volume desagregado de cargas dos principais portos ibéricos -, o que constitui uma tentativa de aferir o atual grau de dependência de Sines no universo do sistema portuário peninsular. Uma segunda, que respeita à evolução das movimentações de cargas nos últimos dez anos, através do Coeficiente de Localização, de modo a perceber qual a tendência de convergência/divergência de Sines em comparação com quatro portos constituídos num arco geográfico que se denominou port range B-B: Barcelona; Valencia; Algeciras e Bilbao, com os quais se pressupõe uma maior competição inter-portuária a nível peninsular, o que constitui um indicador da medida do desempenho portuário global.

Na Seção 4, estuda-se o potencial que Sines encerra na eclosão de um cluster regional suportado na cadeia marítima, enquadrado num cenário prospetivo delineado para o horizonte 2030, inserido no contexto das tendências globais de comércio marítimo, realizado com base nos cenários de procura de transporte e energia elaborados pelo iTREN-2030 e nas previsões macroeconómicas da OCDE, para o mesmo período: Cenário de Recuperação Moderada.

Por fim, na Seção 5, procede-se à apresentação das conclusões finais que sintetizarão os resultados obtidos em todas as análises efetuadas ao longo das diferentes Seções e que serão expostas sob a forma de um relatório final.

DINÂMIA'CET - IUL, Centro de Estudos sobre a Mudança Socioeconómica e o Território 


\section{O PORTO DE SINES: PASSADO, PRESENTE E FUTURO}

\section{Passado}

Em 1971 foi tomada a opção de se construir uma nova refinaria de grande dimensão no sul do país, em local que reunisse as condições de um porto de águas profundas para realizar operações de acolhimento de grandes petroleiros, procedendo-se posteriormente à reexportação de refinados. Este empreendimento faria com que o país visse aumentada a sua capacidade de refinação com a qual se iriam lançar as bases duma indústria petroquímica diversificada. Era um projeto que se pretendia integrado, dotado de instalações e equipamentos apropriados, de modo a atrair a instalação de outras atividades industriais. A visão subjacente era pois de teor "concentracionista" com o melhor ordenamento do território como base dos princípios do progresso harmónico e equilibrado de todas as regiões.

Sines representou uma tentativa de criação de um polo de desenvolvimento cuja vantagem seria a suscetibilidade de atenuar a forte atração exercida pelas cidades de Lisboa e Porto e de contrariar os efeitos geradores de deseconomias que estas regiões, já na altura congestionadas, começavam a apresentar. No entanto, Sines representou efetivamente uma situação de industrialização local sem promover desenvolvimento regional e não se constituiu como um centro dinamizador do(s) Alentejo(s) ou do sul do país. Os efeitos da sua presença apenas se fizeram sentir na faixa litoral, proporcionando indicadores económicos surpreendentemente dissentâneos da realidade do interior: é uma região que apresenta quer um PIB per capita quer um PIB por pessoa empregada invejável, em termos nacionais ${ }^{5}$. O que esses indicadores traduzem em bem-estar e desenvolvimento económico é o que se pretende replicar para a dimensão regional.

\section{Presente}

Até recentemente, Sines, no sentido estrito, resumia-se ao papel de complexo industrial e a um mesmo tempo era sinónimo de porto cuja vocação energética lhe permitia ser considerado como ativo estratégico, embora longe de contribuir verdadeiramente para a diminuição da dependência conjuntural que caracteriza a nossa economia. A sua nova configuração, iniciada em 2003 com a aposta no segmento da carga contentorizada, veio dar-lhe um novo alento e permitir-lhe, ao ter-se libertado da sua dependência extrema como porto petroquímico, criar novas possibilidades de negócio por via da diversificação da carga (Gráfico 1). A breve prazo, a sua nova natureza como porto aberto a diferentes mercados pode impulsionar, através da

\footnotetext{
${ }^{5}$ O PIBpc era, em 2008, o 2.0 logo depois da Região da Grande Lisboa e o PIBppe era, em 2009, o $1 .^{\circ}$ do país. (in: DPP, Desenvolvimento Sustentável e Competitividade, Informação Socioeconómica, 1. ${ }^{\circ}$ Trimestre de 2011).
} 
participação de novos agentes na criação de polos logísticos e industriais ao longo da cadeia de distribuição, - ação -, a que os efeitos da dinâmica portuária se alarguem ao hinterland - reação -, reformatando o porto de Sines na lógica de eixo privilegiado no cruzamento das rotas marítimas mundiais.

Gráfico 1: Movimentação de contentores no Porto de Sines (2003-2011)

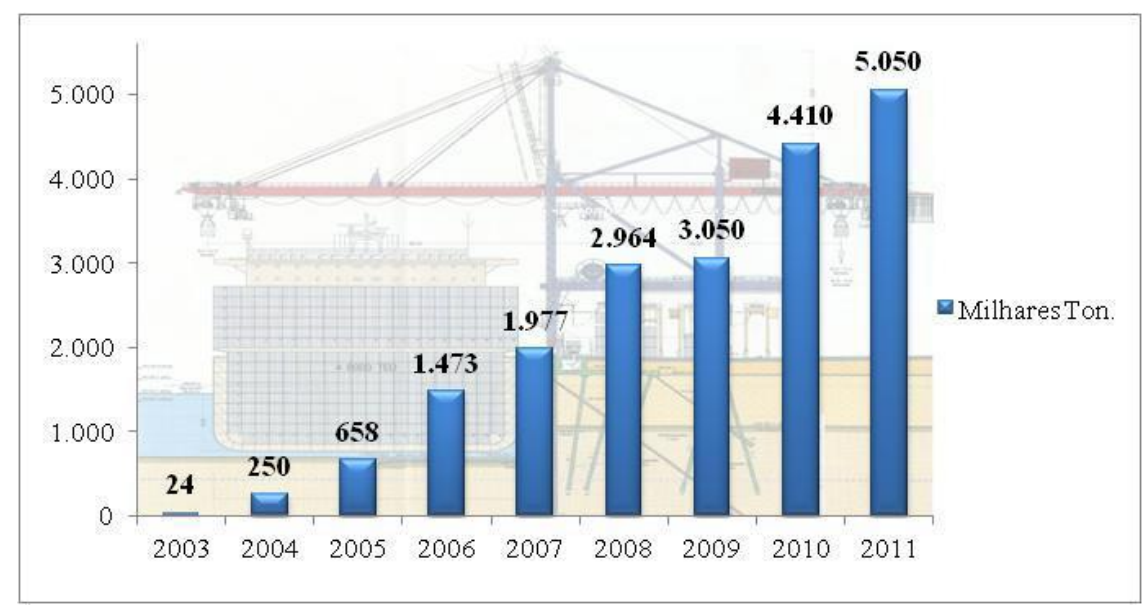

Fonte: Elaboração própria (a partir de dados da APS).

A Administração Portuária de Sines (APS) administra as infraestruturas entregando a exploração e a manutenção dos terminais à iniciativa privada em regime de concessão - a superestrutura. Este regime, denominado Landlord port no jargão internacional da gestão portuária, revela um quadro estrutural que, tal como Ng e Pallis (2010) assinalam para o caso dos portos gregos, envolve a posse e a intervenção governamental: o conceito de bem público é prevalecente e as autoridades nacionais atuam como reguladoras através de administrações portuárias públicas controladas pelos Estados (board of directors), em contraste com os portos britânicos, tendencialmente privados ou do norte da Europa, administrados por juntas camarárias (board of advisors), na tradição do modelo hanseático.

O modelo Landlord port é aquele que apresenta uma tendência global de adoção (Tovar, Trujillo e Jara-Díaz, 2004; Verhoeven, 2009). No caso de Sines a propriedade assume a natureza pública e, as atividades de carga e descarga nos seus terminais, o concessionamento. No entanto, mesmo atuando dentro deste quadro jurídico específico, a APS realiza funções simultaneamente como Landlord port, como regulador e como operador. Como Landlord port, gere os ativos do porto sob sua jurisdição. Refere-se nomeadamente ao fornecimento de infraestruturas como os cais e molhes de amarração ou à dragagem dos fundos. Como regulador, a APS define o quadro regulatório em termos de tarifas, alfândega e procedimentos de segurança. Como operador, fornece o abastecimento diário a navios - serviços de pilotagem e de bancas.

DINÂMIA'CET - IUL, Centro de Estudos sobre a Mudança Socioeconómica e o Território ISCTE-IUL - Av. das Forças Armadas, 1649-026 Lisboa, PORTUGAL

Tel. 210464031 - Extensão 293100 E-mail: dinamia@iscte.pt www.dinamiacet.iscte.pt 
O ativo mais valioso de um porto, pelo seu valor intrínseco e escassez, é a terra. No modelo Landord, a terra é propriedade de um organismo público ou da própria autoridade portuária, enquanto a gestão das superestruturas é entregue à participação do setor privado, dando origem a que o foco da estratégia competitiva se tenha deslocado do porto propriamente dito para os terminais. Em Sines, o terminal de contentores foi concessionado à PSA, um operador mundial especializado na movimentação de terminais de contentores, o qual fixa os preços dos serviços por ele realizados. O determinante por detrás da opção de concessionamento destas atividades parte da redução da postura burocrática e da aplicação da flexibilidade laboral e do empreendedorismo ( $\mathrm{Ng}$, e Pallis, 2010), porque as autoridades portuárias apresentam tipicamente maus níveis de desempenho na gestão destas superestruturas, (The World Bank, 2007), por motivos da redução do esforço financeiro público (Tovar, Trujillo e Jara-Díaz, 2004) e da alteração da cultura empresarial (Verhoeven, 2011), embora a teoria económica não consiga provar de forma inequívoca estes pressupostos (Tongzon e Heng, 2005).

Como entidade dependente da tutela do Ministério da Economia, as grandes linhas programáticas são emitidas por este órgão governativo. Deste modo interessa descortinar o que se propõe implementar em termos de políticas portuárias e conexas. Do Plano Estratégico de Transportes 2011-2015 (PET) aprovado em Outubro de 2011, destaca-se a importância que agora se atribui ao mar, relevando daí a sua estratégia como fronteira natural e como fonte de recursos ao longo da nossa ZEE, sendo aliás o único sector da economia ao qual é atribuído um esforço de investimento para os próximos anos (PET: 70). Segundo este Plano, o sector marítimo-portuário desempenha um papel fundamental a favor do desenvolvimento do país devendo-se portanto melhorar as exportações por via marítima e reforçar a competitividade do país neste sector.

\section{A cadeia marítima e a macroestrutura portuária}

Os quatro elementos funcionais principais que definem um interface marítimo-terrestre são: foreland, hinterland, modos de transporte e sistema portuário.

Quanto ao primeiro, foreland, é acima de tudo o espaço marítimo no qual um porto desempenha relações comerciais e pode ser identificado com o ponto de origem das redes marítimas (maritime chain). As redes marítimas representam todos os movimentos portuários, de logística e de distribuição. Quanto ao segundo, hinterland, considera-se o espaço interior com o qual um porto mantém relações comerciais. Este pode ser dividido em hinterland principal - espaço geográfico de mercado para o qual um terminal é o mais próximo - e hinterland competitivo, utilizado para descrever as áreas de mercado sobre as quais o terminal tem que competir com outros pelo negócio. A noção de hinterland principal com limites bem definidos tem-se esbatido porque muitos hinterland se tornaram descontínuos, um processo facilitado pelo desenvolvimento de corredores e terminais terrestres (Rodrigue, Comtois e Slack, 2006). No 
entanto, em termos teóricos, pode-se concluir que o hinterland principal de um porto é normalmente contínuo. Já o hinterland competitivo tende a ser descontínuo devido à densidade da origem ou destino das cargas ser menor, ao efeito da acessibilidade dos corredores de transporte e dos terminais terrestres.

Figura 1: Localização de Sines na Cadeia Marítima (fluxo outbound).

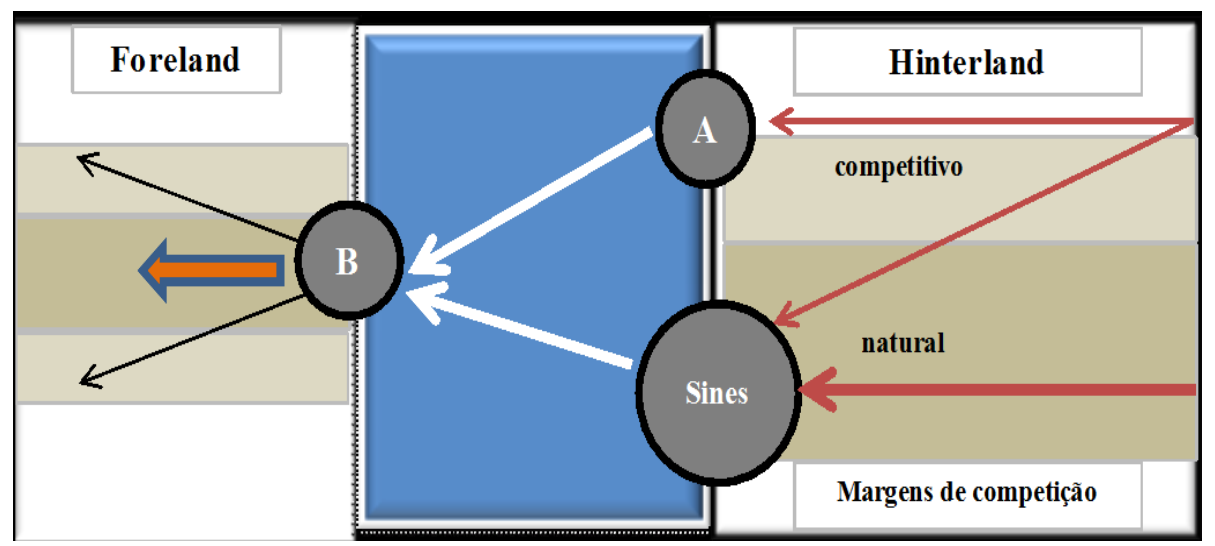

Fonte: Elaboração própria (a partir de Rodrigue, Comtois e Slack, 2006).

Cada modo de transporte está estruturado como um corredor que permite o acesso ao hinterland e às plataformas logísticas do interior (inland hubs) as quais atuam como centros intermodais e transmodais. Quanto ao último conceito, o sistema portuário pode neste caso ser visto como o conjunto de infraestruturas intermodais que servem as operações portuárias.

\section{Futuro}

A expansão do Canal do Panamá, com a ligação direta do Pacífico ao Atlântico de navios de maior envergadura, com os ganhos de eficiência e de escala daí decorrentes poderá originar um aumento do fluxo de trocas entre a bacia do Pacífico, ambas as costas da América do Norte, o Mercosul e a Europa. Sines surge como uma frente atlântica nesta batalha ao pretender captar este trânsito, o chamado fluxo eastbound. A questão que se coloca é se o seu posicionamento geoestratégico e as potencialidades que encerra lhe permitirão, e de que forma, atingir tal desiderato.

Ao contrário do que tem sido antecipado para os portos das costas norte-americanas e para o triângulo do transhipment caribenho, os estudos efetuados pela PCA (Panama Canal Authority), não incidem sobre as tendências de crescimento no volume de cargas na rota Ásia-Europa mas sim Américas-Europa e Américas-Ásia. No que diz respeito aos portos da Europa, pressupõe-se a continuidade do grosso do tráfego via Suez o qual apresenta o caminho mais curto entre a Ásia e a Europa $(-2.100 \mathrm{Km}$, aproximadamente). Os efeitos produzidos com o alargamento estarão dependentes de várias condicionantes, nomeadamente das tendências de crescimento da economia mundial, (para a qual concorre o maior ou menor grau de protecionismo comercial 
adotado por cada país), dos preços dos combustíveis de origem fóssil (bunker prices) e do valor das taxas a aplicar por TEU que transite pelo Canal. A primeira condicionante tem um grau superior sobre as restantes (efeitos diretos sobre o volume de comércio), a segunda atua sobre os custos de transporte marítimo (o que pode implicar a escolha de rotas terrestres como a transiberiana como alternativa) e a terceira, mais dependente da vontade dos investidores, pode fazer erodir o ganho obtido pelos armadores na opção Panamá em detrimento do Suez e logo na sua atratividade.

No caso concreto de Sines como porto concentrador de tráfego, as condicionantes não se resumem apenas às variáveis acima elencadas. Os portos não são escolhidos por mero acaso, contribuindo para isso vários fatores. Ducruet e Notteboom (2010) apresentam onze fatores condicionantes da competitividade inter-portuária, Tongzon (2005), sugere oito, enquanto Vitsounis (2009) aponta nove e Zondag (2008) cita sete. Se alguns destes fatores são endógenos e resultam do esforço que as administrações portuárias devem prosseguir no âmbito das grandes opções políticas nacionais, já outros serão de carácter exógeno e como tal, passíveis de não serem controlados ${ }^{6}$. Uma verdade é certa: a inexistência destas qualidades pode fazer inverter a capacidade de Sines em atrair fluxos de tráfego que serão absorvidos inevitavelmente pelos competidores e originar um resultado neutro naquilo que se espera obter com as novas rotas trans-Atlântico que se projetam.

\section{As linhas de serviço, a escolha dos portos e o conceito de centralidade}

Cullinane e Wong (2012) afirmam que: "the position of a particular port within the network port hierarchy relies upon the number of significant flows connected to the port and the origins/destinations of those flows". Na realidade, as principais linhas de serviço de tráfego de contentores ao redor do mundo contemplam, nas suas escalas, uns meros 10 a 15 portos considerados os mais importantes (Rudel e Taylor, 2000); a rede marítima global está fortemente polarizada em alguns poucos grandes portos (Ducruet e Notteboom, 2010). Ora, os portos não são escolhidos por acaso ou por aparentes vantagens que o observador, incauto ou desconhecedor da rede global de transporte marítimo, lhes possa porventura atribuir. Ducruet e Notteboom (2012), referem que "a escolha de um porto é função dos custos e da performance globais da rede", definição que remete para a análise de tarifários e de desempenho portuários. As linhas determinam os portos que escalam com base nas parcerias que têm e nas redes logísticas que integram, dando os armadores obviamente preferência aos portos onde operam os

\footnotetext{
${ }^{6}$ Utiliza-se um método heurístico na aplicação dos fatores condicionantes da competitividade, considerados como sendo hipoteticamente os mais importantes na escolha dos portos por parte das companhias marítimas, nomeadamente as de transporte de contentores, perante o advento do alargamento do Canal do Panamá: i) Posição geográfica; ii) Eficiência; iii) Conexões ferroviárias do hinterland; iv) Acesso a grande número de consumidores; v) Profundidade das águas do porto; vi) Número de Linhas Regulares; vii) Desempenho financeiro; e, viii) Grau de congestionamento.
} 
seus próprios terminais. Dada a incursão destes agentes nas atividades logísticas em terra, o seu papel na seleção dos portos tornou-se ainda mais preponderante do que anteriormente (Brooks e Pallis, 2008). Isto significa que os portos hoje em dia possuem menos poder nas suas relações com os clientes (Brooks, Schellinck e Pallis, 2011: 17). Segundo Wilsmeier e Notteboom (2009), a configuração das linhas de serviço marítimo não são apenas o resultado de fatores exógenos relacionados com o desenvolvimento do comércio e com a dispersão da atividade económica no hinterland. Os fatores endógenos ligados ao ambiente local do porto, o acesso ao hinterland, as estratégias dos players do mercado e as políticas governamentais têm um claro impacto na forma como as regiões se ligam. O investimento público realizado nas infraestruturas básicas e na interconectividade do hinterland jogam uma cartada fundamental ao permitirem ligações terrestres rápidas, eficazes e confiáveis.

Quanto à distância, grandeza física na qual radica o conceito de centralidade - "proximidade aos mercados de origem/destino"- (Ducruet e Notteboom, 2012), contrariamente ao que se pensa, não é o critério que mais peso apresenta na escolha dos portos ou no delinear das rotas. A fiabilidade e a qualidade geral dos serviços (que passa pela interconectividade entre modos e pela rapidez e eficiência das operações) têm um peso superior (Rudel e Taylor, 2000: 6). Estas duas condicionantes são superadas principalmente através da verticalização de operações em terra por moto próprio ou através da constituição de alianças estratégicas.

A centralidade que se atribui a Sines resulta do seu posicionamento geográfico na encruzilhada de várias rotas marítimas este-oeste (ou equatorial), norte-sul e diagonais. No entanto, se as linhas de serviço não fizerem escala em Sines, apenas se poderá observar navios a passar ao largo, não se retirando disso quaisquer dividendos. O Estreito de Gibraltar é um ponto de passagem estratégico da global beltway o que constituiria certamente uma vantagem de localização para Sines, se o investimento na carga contentorizada tivesse sido realizado década e meia antes. Por essa metamorfose passaram vários portos do Mediterrâneo em que a falta de adequação tecnológica ter-se-á transformado em vantagens comparativas para os grandes portos do Norte, os quais não desprezaram a oportunidade de aumentar a sua posição dominante. Esse panorama sofreu entretanto grandes alterações e vários portos ao longo da rota principal recolheram grandes benefícios dessa sua reestruturação. Este novo protagonismo possibilitou a alguns portos transformarem-se rapidamente em novos hubs dedicados ao transhipment, por feeder costeiro e por ligações ferro-rodoviárias ao interior, tendo consecutivamente ganho quota no mercado do transporte de contentores e reacendido o tema da melhor opção para os fluxos de carga no interior do continente europeu. Deste modo não se perdeu apenas o "boom" do crescimento deste segmento de mercado como se permitiu que se estabelecessem nas proximidades dois grandes hubs intermédios; Algeciras e Tanger Med. Assim as linhas de 
serviço optaram evidentemente por estes portos e criaram as condições para a posse total ou parcial dos meios operacionais, i.e., dos terminais.

Segundo Ducruet e Notteboom (2010), o grau de centralidade de um porto é uma medida de nível local em que se conta o número de conexões de um porto para outros portos; é uma medida da conectividade, enquanto a centralidade intermédia (betweenness centrality) é uma medida de nível global e é dada através da soma, para cada porto, do número de caminhos mais curtos possíveis dentro de toda a rede; é uma medida da acessibilidade. A escolha dos portos e da sua importância e centralidade já não obedece à equação em que a linha de serviço (o armador) escolhia o porto e a carga (o carregador), escolhia a linha de serviço. "Essa competição deixou de ter a natureza de uma luta entre armadores e portos para uma que envolve as cadeias logísticas" (Meersman, Van der Voorde e Vanelslander, 2002), ou seja, entre as cadeias logísticas que conectam a origem ao destino.

Do exposto pode-se inferir que os portos serão escolhidos em virtude do peso global dos players e condicionados pelas malhas de interesses instalados. Isto conduz-nos à questão da competição inter e intra-portuária.

\section{Competição inter-portuária; transhipment, hubs e gateways}

Mesmo que as condicionantes referidas sejam ultrapassáveis, não é suficiente recolher carga e redistribui-la. Esta atividade (transhipment), mesmo quando é significativa, interage pouco com o hinterland (Rodrigue, 2011: 15) e não adiciona valor às mercadorias. É essencialmente atraente do ponto de vista financeiro para os operadores de terminais e para as AP's, razão pela qual todos os portos de contentores se empenham tanto na captação deste tipo de atividade. No entanto, são fluxos que carecem de efeito multiplicador em termos regionais. O transhipment representa o equivalente marítimo da atividade grossista em terra; serve a continuidade da cadeia de abastecimento possibilitando a entrega dos bens aos distribuidores ou aos clientes finais. Mas, embora esta atividade induza custos (mesmo que o preço do frete já incorpore esta modalidade), ao contrário do que acontece com a logística em terra, não é previsível que qualquer agente possa interromper a cadeia e saltar esse elo.

A atividade de transhipment não está vinculada a um porto específico, mas sim a mercados, ao contrário de um gateway que está ligado à distribuição de mercadorias no interior. A incidência de transhipment é a parcela do rendimento total do porto que é transferido de navio para navio, implicando que o destino final do contentor seja outro porto. Quanto maior for, mais um porto pode ser considerado como um centro de transbordo e uma incidência acima de $75 \%$ coloca o porto como um hub de transhipment "puro" (Rodrigue, 2011) e, em teoria, não possui hinterland mas sim um vasto foreland (Rodrigue, Comtois e Slack, 2009). Um hub de transhipment puro é mais instável em relação a um porto gateway: assim que os volumes de tráfego para os portos

DINÂMIA'CET - IUL, Centro de Estudos sobre a Mudança Socioeconómica e o Território ISCTE-IUL - Av. das Forças Armadas, 1649-026 Lisboa, PORTUGAL

Tel. 210464031 - Extensão 293100 E-mail: dinamia@iscte.pt www.dinamiacet.iscte.pt 
gateway sejam suficientes, os hubs deixarão de ser escalados e podem até tornar-se redundantes, embora vários autores afirmem que em muitos casos, as diferenças entre hubs e gateways se tenham esbatido (Ducruet e Notteboom, 2010; Notteboom, 2012). Isto significa que a escala do movimento de cargas aliada às redes logísticas e infraestruturas de transportes, poderá converter um porto de trasfega num porto de distribuição de bens, se as condições forem promovidas.

Mas, para Sines, nem a simples atividade de transhipment está garantida uma vez que a competição é próxima e forte. Os hubs que concorrem diretamente com Sines estão localizados ao longo da costa sul de Espanha. Outros portos importantes como Huelva (essencialmente graneleiro), A Coruña (de pequena dimensão e pouco profundo) ou Gijón (principal porto peninsular dedicado ao minério) não são vistos como "ameaças" diretas à captação de carga por parte do porto de Sines. Falamos evidentemente de Algeciras. A Maersk, a companhia marítima de referência mundial, escala Algeciras não apenas pelas condições que este porto possui em termos comparativos mas sobretudo porque a Maersk opera aqui o seu próprio terminal de contentores.

No entanto, existe um novo hub do Norte de África, Tânger-Med, o qual oferece desvios marítimos muito baixos e surge como competidor direto na atração de tráfego para Sines. É um porto construído de raiz para se tornar um hub de transhipment puro "low cost" e concorre através das tarifas, as quais têm por base os baixos custos laborais praticados naquele país, entre outros, tais como isenções fiscais e estímulos financeiros ao estabelecimento. Em termos estratégicos, Tânger pode ser visto como uma plataforma de acesso ao continente europeu para bens baratos produzidos no norte de África, servindo os portos do mediterrâneo como porta de entrada. Muito concretamente, este porto pode surgir como concorrente direto devido à presença da MSC e da PSA, que nele operam. Da PSA já se falou, quanto à MSC é o principal operador de linhas de serviço em Sines.

\section{Competitividade e novos fluxos de comércio}

Centrado no estudo dos portos de um port range B-B (Barcelona-Bilbao), com os quais se admite uma maior concorrência ibérica, procedeu-se a recolha documental disponível nos sites dos respetivos portos e ainda a fontes diversas. O modelo conceptual proposto com esses elementos levou à elaboração de uma matriz preliminar (Quadro 1), a qual pode constituir-se como um crivo inicial e ponto de partida para análises mais detalhadas em termos de forças e fraquezas competitivas, numa ótica de fluxos de comércio esperados com o alargamento do Canal do Panamá. 
Quadro 1. Fatores de competitividade inter-portuária. Matriz preliminar de análise das forças e fraquezas do port range $B-B$.

\begin{tabular}{|c|c|c|c|c|c|c|c|c|c|c|c|c|c|c|c|c|c|}
\hline & $\begin{array}{c}\text { Posição } \\
\text { Geográfical }\end{array}$ & & Eficiência & & $\begin{array}{c}\text { Conexões } \\
\text { fernoviania } \\
s\end{array}$ & & $\begin{array}{l}\text { Hinterland } \\
\text { principal }\end{array}$ & & $\begin{array}{l}\text { Fundos } \\
\text { maritimos }\end{array}$ & & $\begin{array}{l}\mathrm{N} . \text { de } \\
\text { Linhas de } \\
\text { Serviços } \\
\text { Regulares }\end{array}$ & & $\begin{array}{c}\text { Desempenho } \\
\text { Financeiro } \\
(\mathbf{2 0 1 0})\end{array}$ & & $\begin{array}{c}\text { Grau de } \\
\text { congestionam } \\
\text { ento }\end{array}$ & & \\
\hline Métrica & $\begin{array}{c}\text { Distância } \\
\text { ao Panamá } \\
\text { (km em } \\
\text { linha reta) }\end{array}$ & $\begin{array}{l}\mathrm{P} \\
0 \\
\mathrm{n} \\
\mathrm{t} \\
\mathrm{u} \\
\mathrm{a} \\
\mathrm{c} \\
\mathrm{a} \\
\mathrm{a} \\
0\end{array}$ & $\begin{array}{c}\text { Produtividade } \\
\text { dos terminais } \\
\text { (ver cálculos } \\
\text { auxiliares) }\end{array}$ & $\begin{array}{l}\mathrm{P} \\
0 \\
\mathrm{n} \\
\mathrm{t} \\
\mathrm{u} \\
\mathrm{a} \\
\mathrm{c} \\
\mathrm{a} \\
0 \\
\end{array}$ & $\begin{array}{c}\text { Distância } \\
\text { ferroviairia } \\
\text { a Madrid } \\
\text { (em Km) }\end{array}$ & $\begin{array}{l}\mathrm{P} \\
0 \\
\mathrm{n} \\
\mathrm{t} \\
\mathrm{u} \\
\mathrm{a} \\
\mathrm{c} \\
\mathrm{a} \\
0 \\
\end{array}$ & $\begin{array}{c}\text { Número de } \\
\text { consunidores } \\
\text { (milhões) }\end{array}$ & $\begin{array}{c}\mathrm{P} \\
0 \\
\mathrm{n} \\
\mathrm{t} \\
\mathrm{u} \\
\mathrm{a} \\
\mathrm{c} \\
\mathrm{a} \\
\mathrm{a} \\
0\end{array}$ & $\begin{array}{c}\text { Metros } \mathrm{ZH} \\
\text { do Terminal } \\
\text { de } \\
\text { contentores }\end{array}$ & $\begin{array}{l}\mathrm{P} \\
0 \\
\mathrm{n} \\
\mathrm{t} \\
\mathrm{u} \\
\mathrm{a} \\
\mathrm{c} \\
\mathrm{a} \\
\mathrm{a} \\
0 \\
\end{array}$ & $\begin{array}{c}\text { (Linhas de } \\
\text { serviço } \\
\text { regulares } \\
\text { excluindo } \\
\text { cabotagem) }\end{array}$ & $\begin{array}{l}\mathrm{P} \\
0 \\
\mathrm{n} \\
\mathrm{t} \\
\mathrm{u} \\
\mathrm{a} \\
\mathrm{c} \\
\mathrm{a} \\
0 \\
\end{array}$ & $\begin{array}{c}\text { Receitas } \\
\text { (liquidas) por } \\
\text { tonelada } \\
\text { movimentada } \\
\text { (Euros) }\end{array}$ & $\begin{array}{c}\mathrm{P} \\
0 \\
\mathrm{n} \\
\mathrm{t} \\
\mathrm{u} \\
\mathrm{a} \\
\mathrm{c} \\
\mathrm{c} \\
\mathrm{a} \\
0 \\
\end{array}$ & $\begin{array}{c}\text { Disponibilida } \\
\text { de de } \\
\text { terrenos. } \\
\text { Entre Mau } \\
\text { (3), Frnco (4) } \\
\text { e Bom (5) }\end{array}$ & $\begin{array}{l}0 \\
\mathrm{n} \\
\mathrm{t} \\
\mathrm{u} \\
\mathrm{a} \\
\mathrm{c} \\
\mathrm{a} \\
0\end{array}$ & \\
\hline Peso $(\%)$ & 20 & & 15 & & 12 & & 12 & & 10 & & 10 & & 8 & & 6 & & Totais \\
\hline Algeciras & 8.143 & 4 & $33 \%$ & 4 & 756 & 2 & $\begin{array}{l}\text { c. } 8 \text { milhões } \\
\text { (Andaluzia) }\end{array}$ & 5 & 16 & 3 & 63 & 5 & 0,49 & 4 & Mau & 3 & 3,54 \\
\hline Barcelona & 8.804 & 1 & $-13 \%$ & 3 & 665 & 3 & $\begin{array}{c}\text { c. } 7,5 \text { milhòes } \\
\text { (Catalunha) }\end{array}$ & 4 & 16 & 3 & 55 & 4 & $0,72(2009)^{*}$ & 5 & Fraco & 4 & 2,83 \\
\hline Bilbao & 8.385 & 3 & $-74 \%$ & 1 & \begin{tabular}{|c|}
$579(a) / 441$ \\
(b)
\end{tabular} & 4 & $\begin{array}{l}\text { c. } 3 \text { milhões } \\
\text { (Pais Basco) }\end{array}$ & 2 & 21 & 5 & 20 & 2 & 0,41 & 3 & Fraco & 4 & 2,65 \\
\hline Sines & 7.850 & 5 & $-44 \%$ & 2 & $\begin{array}{c}1063(\mathrm{c}) / \\
867(\mathrm{~d}) / \\
921(\mathrm{e})\end{array}$ & 1 & \begin{tabular}{|c|} 
c. 2 milhões \\
(Distritos de \\
Setúbal, \\
Beja, Érora e \\
Faro) \\
\end{tabular} & 1 & 17,5 & 4 & 8 & 1 & 0,24 & 1 & Bom & 5 & 2,42 \\
\hline Valência & 8.593 & 2 & $82 \%$ & 5 & 464 & 5 & $\begin{array}{c}\text { c. } 4,7 \text { milhões } \\
\text { (Comunidad } \\
\text { Valenciana) }\end{array}$ & 3 & 14 & 2 & 39 & 3 & 0,33 & 2 & Mau & 3 & 2,95 \\
\hline
\end{tabular}

a) Via Medina-Valladohid-Burgos-Miranda: electrificação integral

b) Via Aranda-Burgos (sem electrificação entre Madid-Colmenar e Burgos)

c) Via Ermidas-Pocerão-Seti-Entroncamento-Abrantes-Torre das Vagens-Elvas-Badajoz-Cirdad Real-Manzanares

d) Via Ermidas-Poceirão-Setil-Entroncamento-Abrantes-Torre das Vargens-Valencia de Alcantara-Caceres

e) Via Ermidas-Poceirão-Casa Branca-Évora e nova linha a construir até Badajoz-Cirdad Real-Manzanares, sem utilização da linha Lisboa-Porto, e com electrificação integral

(Distâncias aproximadas, e sem contar com acessos a terminais (Madid-Abroñigal Coslada-Vicakvaro, Barcelona-Morrot, etc.)

* Refere-se ao ano de 2009. O exercicio de 2010 não foi usado comso indicador uma vez que apresenta um resultado de exploração excepcional em $41,7 \mathrm{ME}$ em vintude de contablizações financerias fora da atividade de exploração normal

A pontuação final que Sines recolhe é pouco animadora. Dos fatores passiveis de serem incrementados ressalta a aposta nas ligações ferroviárias, o alargamento da área de influência estratégica do hinterland competitivo e o desempenho financeiro como critérios alvo de melhorias contínuas. Certamente que a escolha de outros fatores poderiam influenciar o resultado final (a escolha do parâmetro ambiente de negócios ou residencial poderia atribuir uma pontuação superior a Sines, por exemplo), ou até alterações nas ponderações exerceriam alterações no ranking. De igual modo, sabendo que a fiabilidade e a qualidade do serviço são critérios que recebem maior importância do que a localização (Rudel e Taylor, 2000), pode-se estar a ser generoso em demasia na atribuição de um peso tão elevado a este fator. No entanto, com esta análise pretende-se acima de tudo proceder a um estreitamento dos critérios que influenciam a escolha de um porto concentrador de cargas, outros poderiam igualmente, com justeza, ser utilizados. A identificação e escolha de um porto particular é, ao final de contas, decisão dos grandes armadores mundiais, os quais determinam se as operações de um dado porto são factíveis e lucrativas; mas a decisão de investimento em infraestruturas que ofereçam 
um serviço adequado de conexões ferroviárias ao hinterland, por exemplo, já não depende deles, e isso constitui um paradoxo, uma vez que é um fator extremamente importante que pesa na decisão de escolha. No entanto, a presença de infraestruturas não garante necessariamente o tráfego uma vez que os armadores podem selecionar os portos em que prestam serviços à medida que se registem mudanças nas oportunidades de negócio (Rodrigue, Comtois e Slack, 2009).

A eficiência financeira medida em receitas líquidas por tonelada, em Sines, apresenta o pior registo entre os principais portos ibéricos, o que faz prova que o movimento de granéis apresenta menores resultados por tonelada que a carga unitizada, com maior valor, embora estes indicadores financeiros não demonstrem o desempenho do porto mas sim da AP. Os indicadores nos quais se fundamentam os critérios de competitividade são subjetivos por natureza, até porque a comparação internacional é difícil de realizar devido à falta de uniformização e de diferentes métodos de recolha. Nesta análise foram utilizados essencialmente como um proxy para a escolha de um porto por parte das companhias marítimas. A função principal dos indicadores não deve ser a de servirem exclusivamente como informação institucional, ou como método de comparação entre portos, mas sim a de fazer com que se assuma que os eventuais benefícios passam do porto para os utilizadores e destes para os consumidores (De Langen, Nijdam e Van der Horst, 2007: 32).

\section{Competição intra-portuária; os diversos agentes}

A pressão crescente da competitividade acontece igualmente ao nível intra-portuário. Sines tal como os restantes portos enfrentam incertezas económicas e volatilidade financeira para os próximos anos, num momento em que o crescimento económico dos países ocidentais se deteriora. De facto, devido à grande incerteza, cada um dos players participantes tentará antecipar-se aos outros através de movimentações estratégicas as quais terão um impacto nas variáveis decisórias cruciais, tais como custos, preços, procura e oferta. Várias forças atuam dentro deste círculo e não estão isentas de conflitos de interesses. Os carregadores (transitários) pretendem obter o melhor preço de frete. Menos serviços fazem incorrer em fretes mais caros por defeitos de concorrência. O operador de logística pretende obter o benefício máximo entre custos e receitas e ganhar quota de mercado aos concorrentes. Os seus instrumentos de poder são as taxas, a capacidade, a flexibilidade e a velocidade de entrega. Como instrumentos do seu poder possuem a política de preços a tecnologia usada e o valor acrescentado ao serviço. Do lado dos operadores dos terminais assistiu-se à introdução da capacidade fixa na descarga dos terminais e ainda a uma política de redução dos preços. As operações de carga/descarga são uma atividade intensamente globalizada. Os portos também pretendem a maximização dos lucros. Complementarmente poderão querer minimizar os custos através da cadeia de abastecimento, ou

DINÂMIA'CET - IUL, Centro de Estudos sobre a Mudança Socioeconómica e o Território 
ainda a maximização do volume de carga manuseado. As suas ferramentas negociais são o preço praticado, o acesso marítimo do porto e a política de concessões.

Concluindo, cada ator no seio das atividades dentro e fora dos perímetros portuários, tem a sua própria agenda e ferramentas para conseguir atingir objetivos estratégicos. No entanto, a maioria dos portos acaba por depender do comportamento dos seus maiores e mais influentes clientes: os armadores. Os objetivos principais dos armadores são a minimização dos custos gerais. Para isso dispõem de instrumentos como o poder de negociação, o qual em última análise dependerá do seu. O perigo da dependência de uma companhia de navegação reside no potencial de deslocalização, o que no caso de Sines seria desastroso. Como as penalizações por deslocalizações são relativamente suaves, as linhas de serviço têm tendência a alterar os seus portos de escala com relativa facilidade.

\section{Eficiência, produtividade e fiabilidade}

A eficiência do sistema portuário é um fator crítico para a eficiência dos próprios países (Tongzon e Heng, 2005) e é apontado por vários autores como sendo o principal fator na escolha de um porto (Aronietis, et al, 2010), razão pela qual houve a preocupação que ocupasse o segundo lugar nos critérios condicionantes da competitividade portuária.

O conceito de eficiência, embora distinto, está intimamente relacionado com o conceito de produtividade, muito por causa da ideia que um porto (ou qualquer empresa), melhora o seu rendimento quanto mais eficiente e produtivo seja (Serrano e Trujillo, 2006). Como fator de competitividade, a eficiência pode medir-se em termos de desempenho financeiro ${ }^{7}$. Segundo Goss, (1990: 211): “Qualquer melhoria na eficiência económica de um porto vai melhorar o bem-estar económico através do aumento dos excedentes para os produtores dos bens exportados e excedente dos consumidores para os consumidores finais das mercadorias importadas". Para muitos portos o aumento das cargas movimentadas e desse modo a produtividade dos terminais, tornou-se um desafio a enfrentar, principalmente para os portos que recebem grandes navios porta-contentores, os quais, em virtude do slow steaming, colocam uma grande pressão nas operações portuárias em termos de tempos de resposta a cumprir (ship turnaround times). Quanto mais tempo um navio permanece atracado mais caro será o preço final a pagar, o que nos remete para a questão da produtividade. A produtividade, ou eficiência operacional, é medida através da taxa de utilização do equipamento e, ceteris paribus, a falta de capacidade portuária pode dar origem a congestionamentos e atrasos podendo isto ser mitigado através da introdução de melhor equipamento tal como pórticos semi-automatizados. Outras

\footnotetext{
${ }^{7}$ A eficiência financeira resulta do somatório das diferenças dos custos a dividir pelos proveitos obtidos em cada segmento de carga. No caso de Sines, e para o global da atividade de movimentação de cargas, a medida da eficiência pelo rácio cargas/proveitos financeiros é inferior a qualquer dos portos ibéricos com que Sines compete.
}

DINÂMIA'CET - IUL, Centro de Estudos sobre a Mudança Socioeconómica e o Território ISCTE-IUL - Av. das Forças Armadas, 1649-026 Lisboa, PORTUGAL

Tel. 210464031 - Extensão 293100 E-mail: dinamia@iscte.pt www.dinamiacet.iscte.pt 
medidas de eficiência operacional lidam com capital e trabalho, ausentes deste estudo por se considerar que, mesmo sendo imperfeita, a análise da produtividade de um porto com base na movimentação de cargas totais continua a ser a mais simples de realizar e à qual os portos na sua maioria recorrem. $\mathrm{Na}$ análise da produtividade foi utilizada uma função de produção média, em que o movimento total, em TEU, do porto é função do número de terminais, do comprimento do cais e do número de gruas-pórtico em utilização, tendo-se apurado as diferenças entre o potencial de movimento anual de TEU com o real (Anexo 1). Neste aspeto, Sines apresenta fraca competitividade com os seus 4 pórticos (o quinto foi instalado em 2012 e o sexto também já o foi), principalmente se comparado com Valencia, que ultrapassa, em muito, a média do registado nos outros portos, mesmo sabendo que quando um porto ultrapassa a sua capacidade planeada isso pode originar ineficiências. Desta avaliação não pode no entanto ser omissa que a produtividade dos terminais não representa a produtividade do porto, nem o desempenho portuário pode ser confundido com o desempenho dos terminais (De Langen, Nijdam e Van der Horst, 2007: 24).

A fiabilidade do serviço é o resultado global de vários parâmetros, ou de bons ou maus indicadores operacionais (rapidez e flexibilidade das operações, atrasos nas operações de carga/descarga, greves e outras perturbações sociais) e representa a perceção que os clientes têm do desempenho geral do porto. Um elemento importante relacionado com a eficiência e a confiabilidade dos portos é o fator trabalho. Os custos do trabalho representam cerca de $60 \%$ a $70 \%$ dos custos operacionais, mesmo em terminais de contentores capital-intensivos. Como a procura de trabalho varia bastante de um dia para outro, os acordos laborais devem ser suficientemente flexíveis para corresponderem à oferta de trabalho, sem impor encargos excessivos, reduzindo o tempo de permanência dos navios no porto e o proporcional risco de rutura (Merk et al, 2011: 26). Ao final, a fiabilidade traduz-se na leitura conclusiva resultante da eficiência e produtividade, fornecendo a métrica da reputação de um porto.

\section{A medida do desempenho portuário: eficiência ou eficácia?}

Brooks e Pallis (2008), definem a estratégia como referente a fatores associados ao âmbito dos serviços prestados e do mercado portuário (product-market scope) e ao plano estratégico em si. Segundo os autores, o desempenho estratégico pode ser avaliado por meio de indicadores de desempenho internos (eficiência) ou externos, por parte dos stakeholders (eficácia). Ainda segundo estes autores, eficiência e eficácia são conceitos relacionados mas distintos. Se o operador de terminal decidir aumentar a eficiência do terminal e para obter isso mantenha mais navios ancorados em espera, a utilização do terminal aumenta mas o tempo de espera sobe, o que não serve as expetativas dos clientes. Desta opção resultará um tradeoff; a eficiência é atingida à custa da eficácia. A eficácia está portanto relacionada com as expetativas dos diversos 
stakeholders, as quais nem sempre são coincidentes. As AP's focalizadas no cliente tendem a ter uma postura de eficácia, a qual, segundo Brooks e Pallis (2008), mede: “(...) how well the firm or agency uses its strategies, structures, and task environment to meet its mission and stated goals". A diferença entre administrações portuárias que seguem uma linha de eficiência e outras que prosseguem uma gestão baseada na eficácia reside portanto na atenção dada aos indicadores que medem a atividade portuária de modo abstrato, ou de o foco ser centrado nas expetativas dos clientes. A medição da qualidade do serviço, mais do que a sua quantificação, passa por ser de extrema importância porque representa a linha de aferição por parte do cliente; a eficiência é importante para melhorar os níveis de operacionalidade de um porto, mas é de importância secundária, a satisfação do cliente é o indicador crítico que deve ser medido numa organização centrada na eficácia (Brooks e Pallis, 2008: 10).

\section{SINES COMO GATEWAY LOGÍSTICO}

\section{A ZILS (Zona Industrial e Logística de Sines)}

Não é por acaso que a ZILS foi considerada o seguro de vida de Sines pela presidente da APS (entrevista de Setembro de 2008 ao Portugal Global da AICEP). De facto assume-se neste trabalho que o desenvolvimento integrado de toda a região depende da concentração de indústrias diversificadas que, através da transformação de recursos específicos locais em vantagens comparativas, promovam o emprego, o empreendedorismo e as competências profissionais. Essa concentração inicialmente na periferia do porto, deverá promover, por efeitos de arrastamento (ripple effect), o lançamento de atividades de grande valor adicionado com base em novas tecnologias e em I\&D, cujas sinergias possibilitem a dinamização das potencialidades económicas regionais.

As plataformas logísticas de mercadorias inserem-se no esquema geral das chamadas cadeias de abastecimento de bens e não podem dissociar-se das políticas de planeamento geral de transportes. A principal utilidade do mercado logístico é o de fornecer cadeias de abastecimento de vários tipos cobrindo todo o processo de produção: desde o transporte de matérias-primas até ao reprocessamento dos desperdícios finais. Segundo o plano apresentado em 2006 e ao qual se atribuiu o nome de "Portugal Logístico", um dos objetivos seria a ligação em rede de bitola UIC aos principais portos atlânticos com as plataformas logísticas. A rede nacional de Plataformas Logísticas apresentada em 2008 (DL no 152/2008, de 5 de Agosto), tendo por base o "Portugal Logístico", pretendia atribuir a essas plataformas uma localização estratégica em termos espaciais. Para o que nos interessa diretamente para este trabalho, sobressai a localização da Plataforma Logística de Poceirão (Projeto LOGZ), com um total de 220ha e desenhada para abarcar os fluxos de mercadorias de e para a Autoeuropa, estando prevista a sua ligação direta

DINÂMIA'CET - IUL, Centro de Estudos sobre a Mudança Socioeconómica e o Território 
com Sines. Já o PET assume a importância estratégica de localização das plataformas logísticas como corredores multimodais e de elos de redistribuição de bens e mercadorias. No que a Sines diz respeito em termos de logística, algumas medidas pontuais surgem da leitura do Plano: uma será a que respeita à implementação da Janela Única Logística (aliás já prevista, desde 2006, ocorrer com a implementação do Portugal Logístico) com base na Janela Única Portuária, o que constitui apenas uma pequeníssima gota de água na aridez com que o Plano contempla o sector.

\section{Corredores de transportes e redes de distribuição}

O desenvolvimento dos modos de transporte intermodais forneceu novas oportunidades as quais por seu lado tiveram um grande impacto na logística associada. Isto produziu um certo paradoxo: segundo Rodrigue, Comtois e Slack (2006), para o cliente, o espaço geográfico tornou-se irrelevante enquanto para o fornecedor deste tipo de serviço, quer as rotas quer os modos de transporte, assumiram uma importância ainda maior. A produção e o consumo mundial mudaram substancialmente a distribuição com o surgimento de sistemas de produção regionais, bem como mercados de grande consumo. Nenhuma única localização pode atender de forma eficiente os requisitos de distribuição de uma rede tão complexa de atividades.

A definição de região urbana considera-a como a hierarquia de determinados serviços e funções enquanto um corredor é uma estrutura que organiza interações dentro desta hierarquia (Rodrigue, Comtois e Slack, 2006). O corredor de transporte fornece a capacidade física de movimentação e favorece a acessibilidade e a circulação dos fluxos de produção, distribuição e consumo (Figura 2). Neste modelo conceptual Sines regula o tráfego de mercadorias inbound e outbound servindo de interface entre os sistemas regional, nacional e global.

Figura 2: Transportes, redes de distribuição e fluxos.

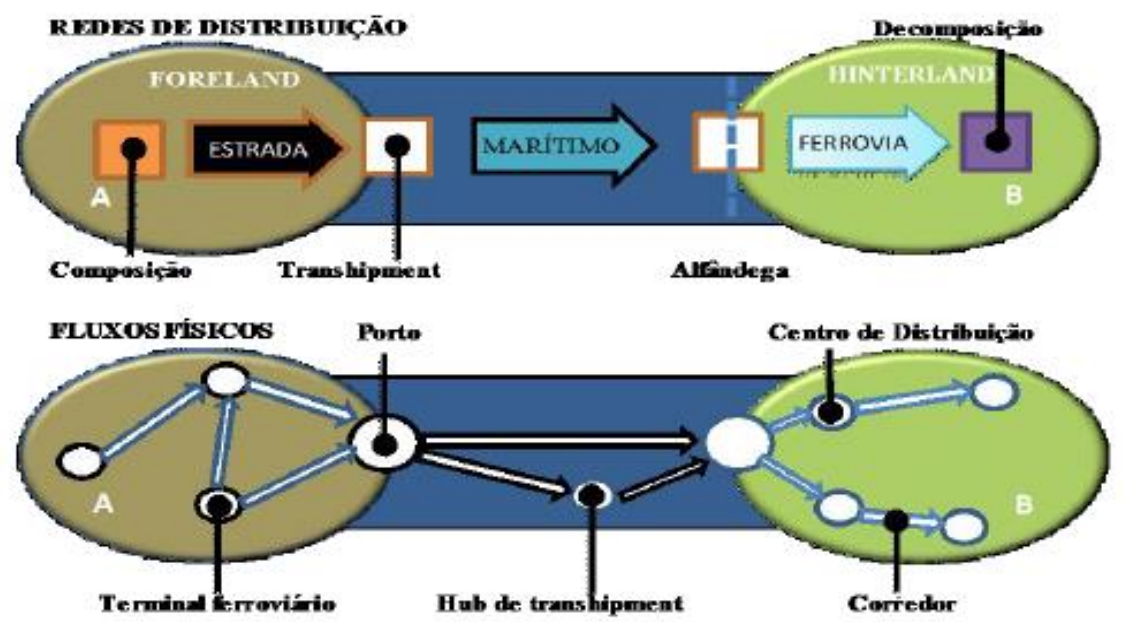

Fonte: Elaboração própria (a partir de Rodrigue, 2006). 
Os corredores têm vindo a tornar-se a estrutura principal para a acessibilidade ao interior e através dos quais os portos ganham acesso aos sistemas de distribuição. As estratégias estão assim cada vez mais a passar pelo controlo dos canais de distribuição de modo a assegurar uma circulação desimpedida da carga contentorizada.

\section{Delimitação da fronteira (estrutura espacial)}

A existência de um "missing link" pressupõe a necessidade de uma ligação direta de Sines à Plataforma Logística de Badajoz, porta de entrada no hinterland competitivo sem a qual não haverá potencial de crescimento devido à exiguidade do hinterland natural (Figura 3).

Figura 3: Apresentação da rede ferroviária de Sines: o "missing link"

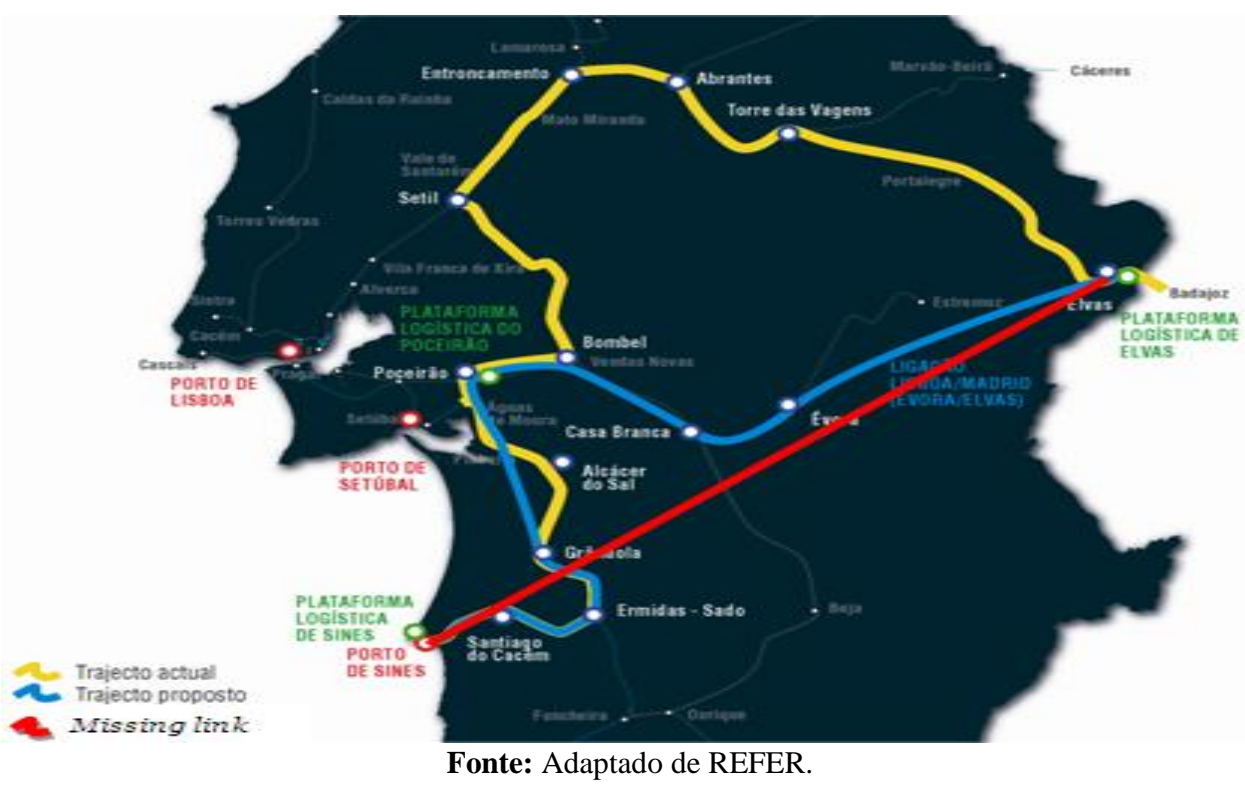

$\mathrm{Na}$ origem do traçado da rede atual reside o facto de Sines ter sido desenhado como porto de granéis sólidos, nomeadamente de descarga de carvão para alimentar as centrais termo elétricas de Sines e do Pego. Esta gincana ferroviária (a amarelo na figura),exemplifica o conceito de friç̧ão de modo visível e faz sobressair a existência de um "missing link", a qual poderia ser uma nova via férrea entre Ermidas e Évora, ou entre Ermidas e Elvas-Badajoz. 


\section{ANÁLISES QUANTITATIVAS: COEFICIENTES DE GINI E DE LOCALIZAÇÃO}

Para se obter uma visão global do mercado portuário nacional e ibérico no qual Sines concorre e como forma de ajudar a conceber ideias que permitam identificar o individual entre o coletivo, recorreu-se a modelos de base estatística cuja utilização nas ciências sociais está bem documentada. Assim, em termos empíricos, procedeu-se a uma análise composta por dois tipos diferentes de abordagem: i) estudo do grau de dependência das cargas nos portos ibéricos continentais mais importantes através do Coeficiente de Gini; e, ii) aplicação do Coeficiente de Localização entre Sines e um port range ibérico para aferir da convergência ou divergência de crescimento registada na última década.

\section{Índice de Dependência de Cargas: o Coeficiente de Gini}

O Coeficiente de Gini é uma medida de desigualdade comumente utilizada para calcular a desigualdade na distribuição de rendimento, mas pode ser aplicada ao grau de concentração que destaca diretamente até que ponto cada porto depende do tráfego de certa carga. Assume-se que um alto coeficiente de Gini mostra uma alta especialização/dependência em determinada carga. Valores próximos de zero indicam uma perfeita igualdade enquanto valores próximos a um revelam uma desigualdade alta. A representação do coeficiente de Gini é dada pela seguinte expressão, conhecida como Fórmula de Brown:

$$
G=\left|1-\sum_{k=1}^{k=n-1}\left(X_{k+1}-X_{k}\right)\left(Y_{k+1}+Y_{k}\right)\right|
$$

$G=$ Coeficiente de Gini do porto $i$

$X=$ Proporção acumulada das cargas quando têm percentagens iguais

$Y=$ Proporção acumulada da percentagem das cargas

$k=1,2 \ldots, 10=$ percentagens das cargas

Nestes termos, e para aferir do grau de diversidade/especialização dos portos nacionais em conjunto com os portos ibéricos, desagregou-se as mercadorias em dez categorias principais. Os portos nacionais escolhidos para esta análise são responsáveis por $97 \%$ do total de mercadorias movimentadas no país por via marítima e os onze principais portos espanhóis, responsáveis por cerca de $90 \%$ do total de cargas movimentadas em Espanha.

O Quadro 2 apresenta a seleção da amostra dos principais portos ibéricos. Os dados utilizados foram retirados das séries temporais publicadas no portal do IPTM, I.P., no caso dos portos portugueses, e do portal Puertos del Estado, no caso dos portos espanhóis, desagregados em 10 tipos de categorias que correspondem a tratamentos de uso de equipamentos e de infraestruturas específicas e referem-se ao ano de 2010.

DINÂMIA'CET - IUL, Centro de Estudos sobre a Mudança Socioeconómica e o Território 
Quadro 2: Portos e âmbito da pesquisa.

\begin{tabular}{|c|c|}
\hline Portos & Cargas (mil. Ton.) \\
A Coruña; Algeciras; & Granéis Sólidos \\
Aveiro; Barcelona; & produtos agricolas \\
Bilbao; Cartagena; & minérios \\
Castellón; & carvão \\
El Ferrol; Gijón; & outros GS \\
Huelva; Leixões; & petróleo (ramas) \\
Lisboa; Setúbal; & produtos refinados \\
Sines; Tarragona; & gases liquefeitos \\
Valencia & Fraccionada \\
& Contentores \\
& Ro-ro \\
\hline
\end{tabular}

Da análise efetuada com recurso ao Coeficiente de Gini (Anexo 2), verifica-se que, (e aqui para o que mais no interessa), dos 5 portos do port range B-B, Bilbao é o porto que exibe uma menor dependência de um certo tipo de carga, podendo-se afirmar que é o porto mais diversificado, apresentando um Coeficiente de Gini de 0,445. Barcelona surge em segundo lugar com 0,472, seguindo-se Sines $(0,677)$, Algeciras $(0,683)$ e, por último, Valencia que, com um índice de 0,764 , é o porto mais dependente de uma dada carga, no caso em concreto, dos bens contentorizados, a carga com uma maior quota relativa (71,8\%), um verdadeiro container port (Anexo 3). No caso de Sines, embora o crescimento do peso da carga contentorizada venha aumentando nos últimos anos, pode afirmar-se que ainda é um porto especializado em granéis líquidos, condição que poderá ser ajustada nos próximos anos se a tendência da contentorização se afirmar. O gráfico de dispersão dá-nos uma ideia mais apurada das diferenças registadas para cada porto (Gráfico 2).

Gráfico 2: Gráfico de dispersão.

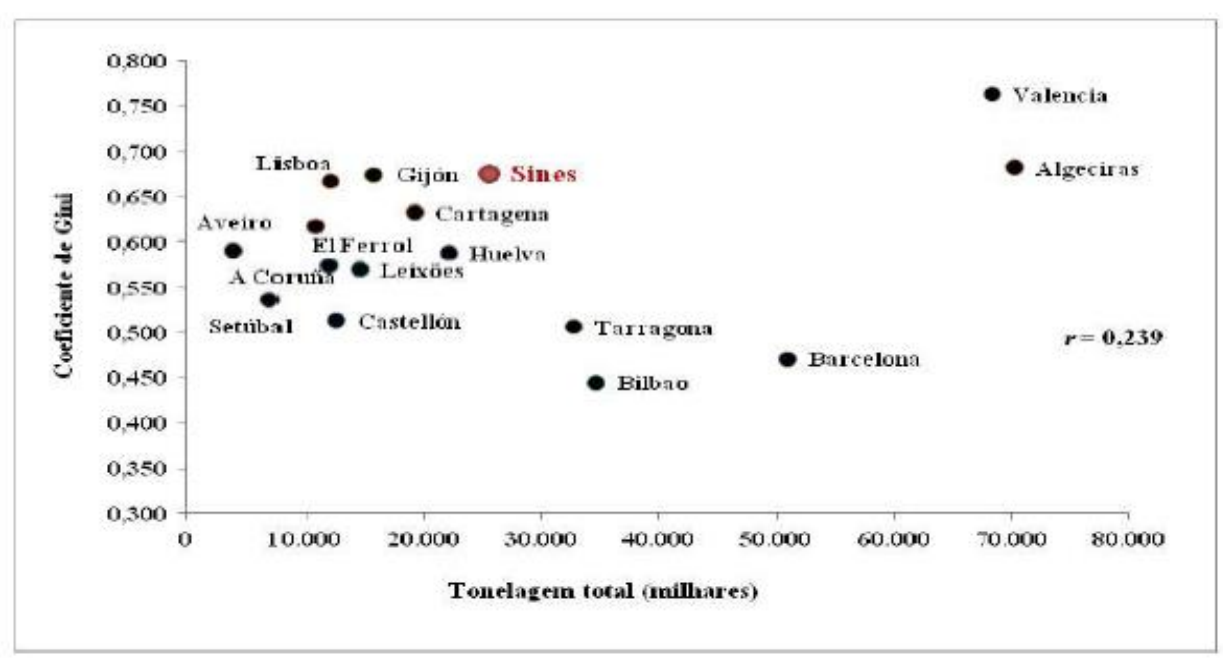

DINÂMIA'CET - IUL, Centro de Estudos sobre a Mudança Socioeconómica e o Território 
O Coeficiente de Localização $(C L)$

O CL foi usado por Lopes (2001: 58-65) para cálculo dos desequilíbrios regionais tendo sido aplicado à repartição da população ativa pelos três principais setores de atividade. Neste estudo, aplica-se o CL à análise do comportamento do volume de cargas dos 5 principais portos ibéricos, comparando-se dois períodos: 2002 e 2011. Pretendeu-se com isso situar os desvios de cada porto em relação à média do port range, ou seja, o que cada um deles deveria ter crescido para acompanhar o movimento, em média, do conjunto dos 5 portos. A finalidade é verificar se o porto que mais nos interessa - Sines -, acompanhou ou divergiu na tendência demonstrada pelos seus principais competidores. Na essência deste estudo temos duas variáveis que se colocam em confronto: o crescimento de um certo tipo de carga (x) e o do total das cargas (y), sendo que para cada porto teremos $\frac{x_{i}}{x}$ e $\frac{y_{i}}{y}$ e como as proporções de cada tipo de carga e do conjunto de cargas que lhe cabem no conjunto.

O CL pode então obter-se a partir de:

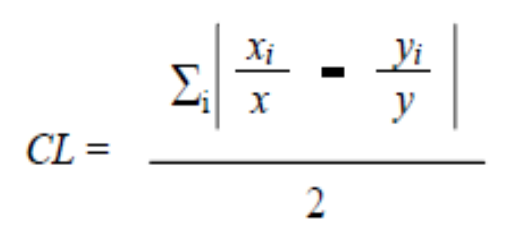

Tratando-se de assimetrias no crescimento, a evolução só pode ser considerada face a um padrão; neste caso esse padrão é o comportamento do conjunto dos 5 portos e a evolução dos desequilíbrios é analisada por comparação da evolução real com a que deveria ter-se verificado para que as diferenças não se tivessem registado.

$$
\delta_{i}=\delta+\left(\delta_{i}-\delta\right)
$$

$\delta$ é a taxa de crescimento registada no periodo para o conjunto dos 5 portos

$\delta_{i}$ é a taxa efetiva de crescimento do volume de mercadorias no porto $i$

Através do Coeficiente de Localização pretende-se verificar o desvio ( $\delta \mathrm{i}-\delta$ ) entre o comportamento de um porto e o comportamento do grupo em geral. Se a variável $\mathrm{x}$ for desagregada em mercadorias por natureza distinta $\mathrm{j}(\mathrm{j}=1,2,3 \ldots \mathrm{m})$, a identidade equivalente a (3.3) pode assumir a forma:

$$
\delta_{i j}=\delta+\left(\delta_{j}-\delta\right)+\left(\delta_{i i}-\delta_{j}\right)
$$


Das expressões anteriores construídas sobre componentes relativas, passa-se ao valor absoluto das componentes multiplicando os dois termos das identidades pelo valor absoluto da variável registado no início do período. De (3.4) passa-se a xijoij cujo somatório ao longo de $j$ origina

$$
\sum x_{i j} \delta_{i j}=\sum x_{i j}\left[\delta+\left(\delta_{j}-\delta\right)+\left(\delta_{i i}-\delta_{j}\right)\right]
$$

$\delta_{j}-\delta=$ componente carga: destaca o comportamento de um tipo de carga no conjunto das cargas (ex. contentores, vs total de cargas)

$\delta_{i j}-\delta_{j}=$ componente portuária (ou global): enfatiza o comportamento de uma carga num porto face ao comportamento dessa carga no conjunto dos 5 portos (ex. contentores no porto $i$, vs contentores no total dos 5 portos)

Como $\sum x_{i j} \delta_{i j}=x_{i} \delta$, chega-se a

$$
x_{i}\left(\delta_{i}-\delta\right)=x_{i}\left(\delta_{i}^{\prime}-\delta\right)+x_{i}\left(\delta_{i}-\delta_{i}^{\prime}\right)
$$

$x_{i}$ representa o volume total movimentado pelo porto $i$ em toneladas,

$\delta_{i}{ }^{\prime}$ é a taxa de crescimento que o porto deveria ter verificado se cada tipo de carga tivesse evoluido como no conjunto dos 5 portos

A componente associada a $\left(\delta i^{\prime}-\delta\right)$ reflete os efeitos esperados das características globais a nível do grupo de portos e por isso se designa por componente global ou "componente portuária", enquanto a associada a $\left(\delta i-\delta i^{\prime}\right)$ que põe em confronto a evolução efetiva do porto e a que deveria ter ocorrido se nela os diferentes tipos de carga se tivessem comportado como, em média, aconteceu no grupo dos portos, se designa por "componente carga". As duas hão-de explicar o desvio $(\delta i-\delta)$ entre o comportamento efetivo do porto e o conjunto dos 5 portos.

O Quadro 3 sintetiza o movimento de cargas registadas no port range, agrupadas em três categorias principais: Granéis sólidos, granéis líquidos e carga geral (que inclui a fracionada e a contentorizada), tendo-se excluído o tráfego Ro-ro uma vez que Sines não apresenta qualquer movimento deste tipo de carga o que causaria sobreavaliação dos dados dos portos que a movimentam. 
Quadro 3: Repartição de carga nos portos em 2002 e 2011 (milhares de toneladas).

\begin{tabular}{|c|c|c|c|c|c|c|}
\hline Tipo Carga & Algeciras & Barce lona & Bilbao & Sines & Valência & $\Sigma$ \\
\hline G. Sólidos & 2.839 & 3.383 & 4.625 & 5.796 & 5.797 & 22.440 \\
\hline G. Líquidos & 17.913 & 9.930 & 13.125 & 14.318 & 1.624 & 56.910 \\
\hline Carga Geral & 32.889 & 18.688 & 12.051 & 26 & 25.393 & 89.047 \\
\hline Total & 53.641 & 32.001 & 29.801 & 20.140 & 32.814 & 168.397 \\
\hline
\end{tabular}

\begin{tabular}{|l|r|r|r|r|r|r|}
\hline Tipo Carga & Algeciras & Barcelona & \multicolumn{1}{c|}{ Bilbao } & \multicolumn{1}{c|}{ Sines } & Valência & $\Sigma$ \\
\hline \\
G. Sólidos & 1.567 & 3.544 & 4.451 & 4.041 & 2.374 & 15.977 \\
G. Liquidos & 23.036 & 10.761 & 19.763 & 16.151 & 4.530 & 74.241 \\
Carga Geral & 53.847 & 28.759 & 9.445 & 5.600 & 58.571 & 156.222 \\
\multicolumn{10}{|c}{ Total } & 78.450 & 43.064 & 33.659 & 25.792 & 65.475 & 246.440 \\
\hline
\end{tabular}

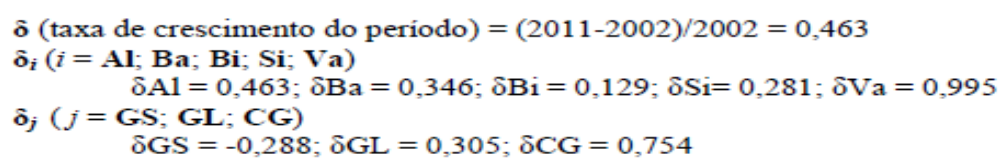

Se multiplicarmos a matriz R02 (ano 2002), pelo vetor $\delta j$ encontramos os acréscimos necessários ao cálculo dos vetores $\delta^{\prime} j$

[ $-0,2880,3050,754] *[\mathrm{R} 02]=[294441614511758271717972]$

donde,

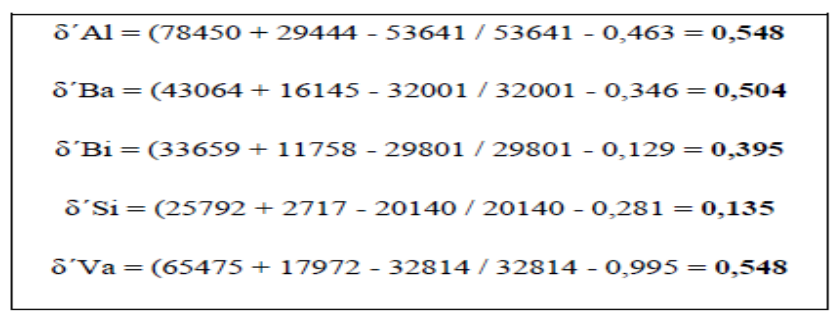

Na posse de todos os elementos para determinação das componentes, resumem-se os resultados no quadro seguinte. Com eles elabora-se a Figura 4 (Shift-share Analysis).

\begin{tabular}{|c|c|c|c|c|c|}
\hline & Algeciras & Barcelona & Bilba0 & Simes & Valencia \\
\hline$D i=\delta i-\delta$ & $0,463-0,463=0,00$ & $0,346-0,463=-0,117$ & $0,129-0,463=-0,334$ & $0,281-0,463=-0,182$ & $0,995-0,463=+0,532$ \\
\hline Componente portuária $=\delta \mathrm{i}-\delta$ & $0,548-0,463=+0,085$ & $0,504-0,463=+0,041$ & $0,395-0,463=-0,068$ & $0,135-0,463=-0,328$ & $0,548-0,463=+0,085$ \\
\hline Componente carga $=\delta \mathrm{i}-\delta \mathrm{i}$ & $0,463-0,548=-0,085$ & $0,346-0,504=-0,158$ & $0,129-0,395=-0,266$ & $0,281-0,135=+0,146$ & $0,995-0,548=+0,447$ \\
\hline
\end{tabular}


Figura 4: Análise Shift-share (Análise das Componentes da Variação).

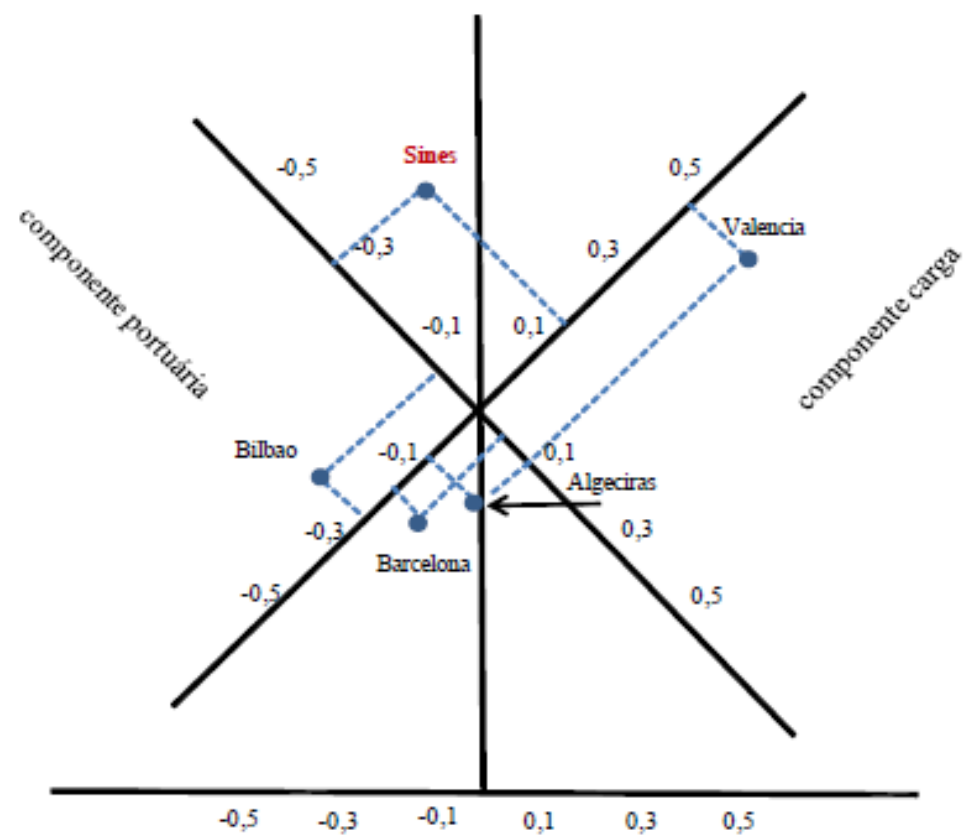

Pela visualização da Figura 4 observa-se que Sines consegue apresentar um crescimento notável na componente carga, a qual, como já se viu anteriormente, assinala a evolução efetiva do porto e a que deveria ter ocorrido se nela, os diferentes tipos de carga se tivessem comportado como, em média, aconteceu no grupo dos portos. O tipo de carga em destaque é a carga geral, nomeadamente o segmento de carga contentorizada. Sines apresenta a segunda taxa superior que, não sendo de admirar (em 2002 esse tipo de carga era inexistente) também demonstra que o crescimento tem sido sustentável. O porto de Valencia é o porto que mais cresce - e mais de destaca entre os portos espanhóis - sendo Bilbao o porto que perde mais terreno na aproximação global com os restantes ao longo deste período de dez anos. Já a componente portuária (ou global), a qual representa a evolução do total das cargas no conjunto dos portos, mostra que Sines apresenta o valor negativo mais elevado dos 5 portos, ou seja, o crescimento observado nos granéis líquidos, não foi suficientemente capaz de corrigir a perda de crescimento global, a qual não terá sido mais penalizada devido ao aumento da carga contentorizada.

\section{SINES COMO CLUSTER REGIONAL}

\section{Economia e Desenvolvimento Regional}

No atual contexto - marcado pela globalização e pela integração económica internacional -, com a crescente mobilidade de produtos, capitais e recursos humanos em direção às economias emergentes, surgem problemas graves às regiões do país, em particular àquelas cujo processo produtivo é muito baseado nas fases rotineiras e massificadas da produção industrial ou marcadas pela estagnação do setor primário, como é o caso do Alentejo Central e de boa parte 
do território a Sul. Este contexto é igualmente marcado pela crescente concorrência entre territórios, bem como pela crescente relevância das questões ambientais que tem vindo a ganhar novas dimensões com as alterações climáticas e a necessidade de substituição de fontes de energia, criando algumas restrições, mas igualmente gerando oportunidades ao desenvolvimento das regiões. A deslocalização empresarial impõe também ela cada vez mais à economia nacional a necessidade de evoluir para atividades intensivas em conhecimento e criatividade, daí a emergência da constituição de clusters suportados numa dinâmica empresarial que apele à inovação e diversificação de negócios, certamente, mas que também recorra às fontes tradicionais de exportação, incorporando vantagens comparativas através da diferenciação e da revalorização dos produtos. A visão de que um aumento do rendimento das regiões mais pobres e um acesso mais equitativo a bens públicos orientados para a satisfação das necessidades básicas conduziriam ao seu desenvolvimento (lógica redistributiva), alterou-se, de modo a ir ao encontro das novas realidades: a necessidade de conjugar os aspetos da coesão económica e social com os da competitividade e com os da sustentabilidade ambiental.

No sumário executivo foi afirmado que, como desígnio nacional, não se pode limitar apenas por apelar à internacionalização das empresas e à descoberta de novos mercados de exportação. É igualmente necessário identificar quais as empresas que apresentam um potencial exportador, porque os mercados de exportação tendem a selecionar as empresas mais eficientes. Daí a importância de se apostar em setores/empresas de alto valor acrescentado ou capital-intensivos, para o mercado externo e, nos trabalho-intensivos ou de menor valor, para o mercado interno, nomeadamente como substituição de importações. Mas a capacidade de colocar bens e serviços nos mercados externos não esgota o processo de internacionalização da produção: a presença de capital estrangeiro é igualmente um fator de competitividade dada a natural seletividade do mesmo. Este assunto adquire uma maior relevância e atualidade se atendermos ao nível de descapitalização em que se encontra a maior parte das empresas nacionais.

\section{O processo de "clusterização"}

Os clusters são definidos como uma população de organizações interdependentes que operam na mesma cadeia de valor e que estão geograficamente concentradas (Rodrigue, Comtois e Slack, 2006). No entanto, no caso específico de Sines este pode ser descrito como sendo um cluster de natureza multidimensional e apresentar alguma descontinuidade territorial. Os portos e as cidades interatuam através de múltiplas dimensões: económica, social, ambiental e cultural, mas no caso de Sines e por força do seu afastamento relativo a grandes cidades (o que passa por ser um beneficio no conjunto de ativos ambientais priceless), o modelo de clusterização gizado passa por ser forçosamente singular. Partindo do ponto embrionário constituído pela ZILS, emerge uma tendência de diversidade das atividades instaladas cujo exemplo mais visível do impacto na economia e no emprego da região são as fábricas da Artlant PTA e da Ibercoal. São

DINÂMIA'CET - IUL, Centro de Estudos sobre a Mudança Socioeconómica e o Território 
unidades desta dimensão, dos sectores de atividade de média-alta tecnologia, de grande valor incorporado, direcionadas para a exportação e para novos mercados, para as quais se deve orientar o esforço de criar condições de atratividade para que Sines se torne um polo tecnológico de excelência e uma referência nacional para atividades subsidiárias. $\mathrm{O}$ alargamento dessa tendência às áreas contíguas será o passo seguinte a planear e a executar. Dentro deste prisma convirá certamente proceder-se a um levantamento exaustivo de todas as capacidades de atração e fixação de indústrias competitivas que possam beneficiar do conjunto de infraestruturas existentes e a desenvolver no futuro próximo, algo digno de figurar nos anais da gestão de grandes projetos a nível nacional (Figura 5).

Figura 5. Um" mega-cluster" regional.

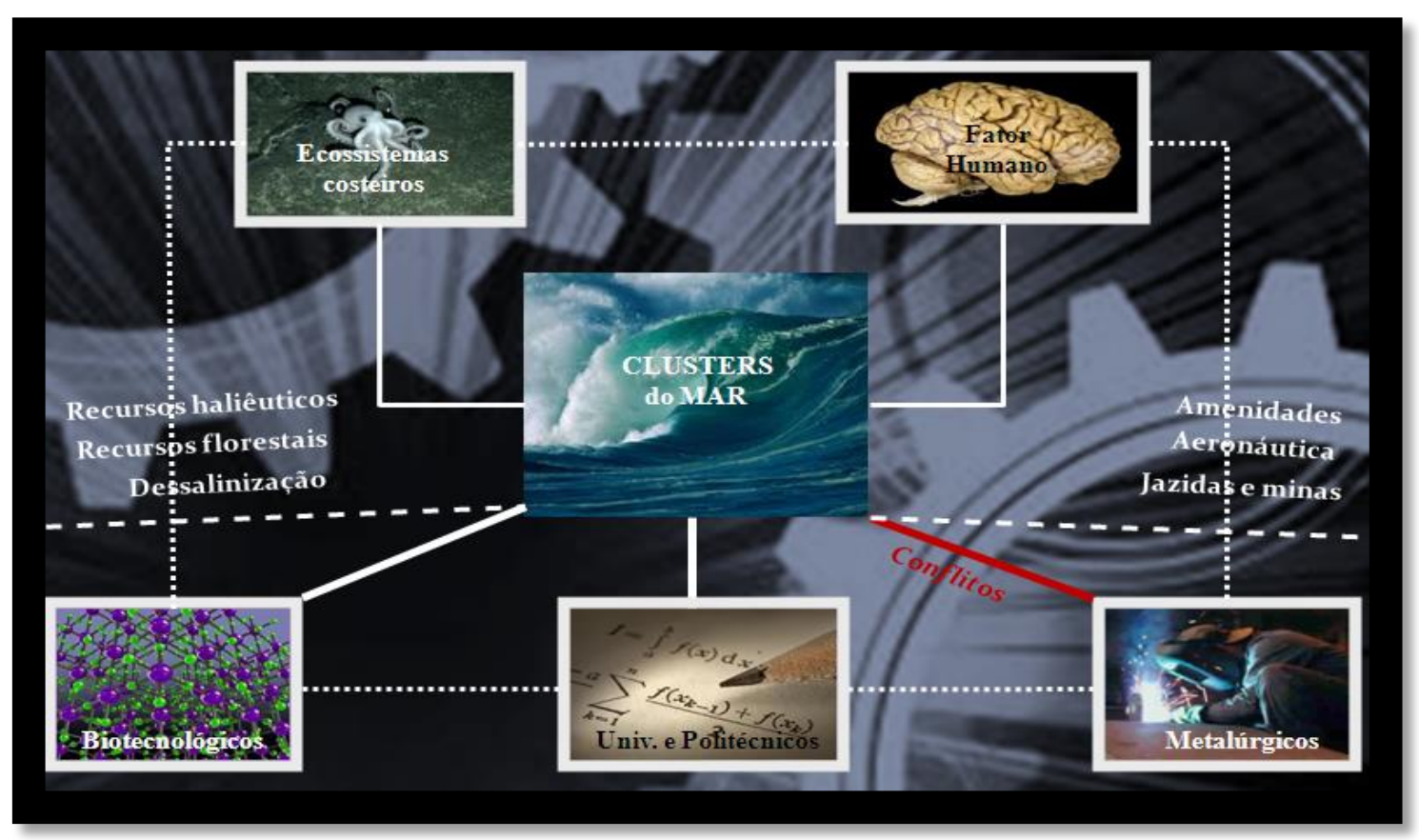

Fonte: Elaboração própria.

O mapa da planificação do desenvolvimento da região deverá obedecer a uma triangulação em que os vértices sejam constituídos por Sines, como "testa de ponte", Beja e Évora, polos naturais para a logística, concentração de atividade industrial e fixação de população. Tratar-seá na verdade de um paralelogramo se os ângulos forem alargados para incluir as jazidas dos mármores de Estremoz, a norte, e a faixa piritosa, a sul. Parte-se portanto da ideia mais circunscrita de pólo de crescimento para uma perceção mais vigorosa e integradora de região de desenvolvimento.

\section{Cenário prospetivo para Sines no horizonte 2030}

A partir do Cenário Integrado elaborado pelo iTREN-2030 para a procura de transporte e de energia, com base nas previsões de crescimento económico para as diversas regiões do mundo e

DINÂMIA'CET - IUL, Centro de Estudos sobre a Mudança Socioeconómica e o Território 
do reflexo que tais ocorrências terão no tráfego de mercadorias transitadas pelo Canal do Panamá, elaboram-se os seguintes três Cenários Prospetivos: i) Cenário de Forte Crescimento; ii) Cenário de Crescimento Moderado; e, iii) Cenário de Estagnação (Quadro 5).

\section{Quadro 5: Cenários Prospetivos para 2030.}
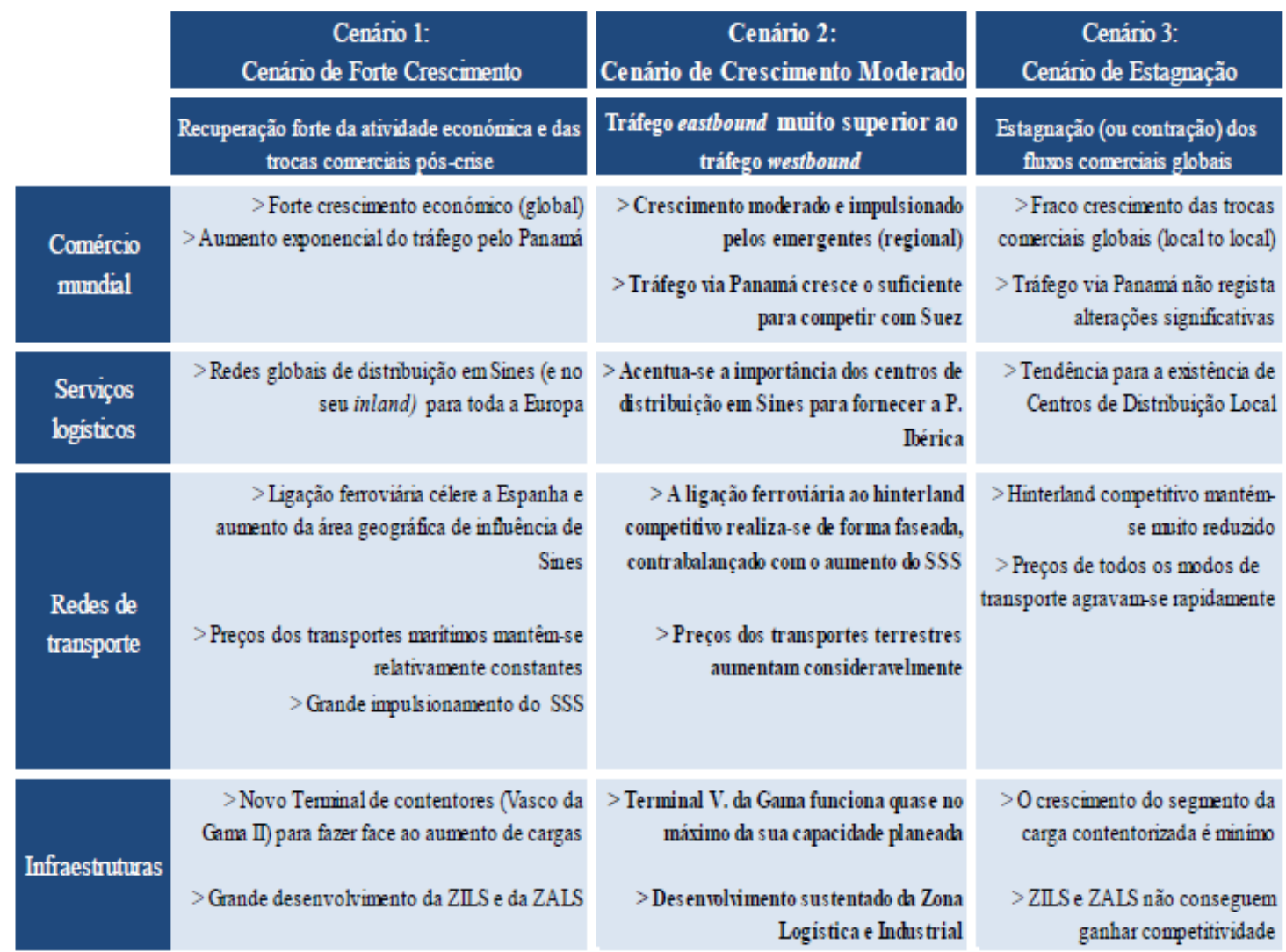

Com uma retoma dos fluxos de tráfego marítimo a níveis pré-crise impulsionado por um sólido crescimento económico dos emergentes e condicionado por um fraco crescimento económico das economias ocidentais, perante uma previsão de procura de transporte marítimo que oscila em consonância com os preços dos combustíveis e em que crescem as pressões ambientais para a diminuição do tráfego associado ao modo terrestre, definiu-se um Cenário de Crescimento Moderado o qual surge como o que reúne mais probabilidades de ocorrer.

A partir do Cenário Crescimento Moderado elabora-se uma análise de sensibilidade adicional (Quadro 6). Sines surge como um porto gateway de entrada e de saída de produtos e commodities na Península Ibérica e de transhipment para portos do Norte da Europa e do Mediterrâneo Ocidental, possibilitado pelo recurso a navios maiores que podem passar pelo Canal do Panamá e ao desvio norte-sul que esse alargamento proporcionou aos armadores efetuar, registando-se igualmente um crescimento dos fluxos de trocas comerciais com o 
Mercosul. O aumento do fluxo de tráfego resulta ainda numa grande oportunidade de crescimento para as redes de distribuição - ferroviárias e marítimas principalmente -, uma vez que o aumento dos preços que incidem sobre o modo rodoviário obriga a uma opção de custos mais reduzidos.

Quadro 6. Testes de sensibilidade.

\begin{tabular}{|c|c|c|c|}
\hline Testes de Sensibilidade & Definição & Aspectos positivos & Aspectos negativos \\
\hline Maiores naxios & $\begin{array}{l}\text { Navios maiores carregam mais mercadorias; econonias de escala favorecem } \\
\text { preços mais reduzidos. (Leva em conta os fluwos originados pelo Canal do } \\
\text { Pamamá en termos de deep-sea e entre os portos da UE, em termos de short- } \\
\text { sea shipping (SSS) }\end{array}$ & $\begin{array}{l}\text { Redução de } \mathrm{CO} 2 \text { por via do } \\
\text { recurso } 30 \text { fbeder. A maior } \\
\text { escala leva a uma potencial } \\
\text { redução de custos portuários }\end{array}$ & $\begin{array}{l}\text { O accéscimo de tráfegó rodoviário } \\
\text { no hinterland poderá ser um dos } \\
\text { resultados; necessidade de } \\
\text { transferir para o modo ferroviário }\end{array}$ \\
\hline Desvio Norte/Sul & $\begin{array}{l}\text { Portos da fachada Atlântica tornam-se mais competitivos. Os armadores } \\
\text { preferemn o transhipment do que escalar portos de maior dimensão mais a } \\
\text { Norte Sines, porto de águas profimdas, recebe navios post-Panamax }\end{array}$ & $\begin{array}{c}\text { Diminuição das tonkm devido } \\
\text { aos menores trajectos percorridos }\end{array}$ & $\begin{array}{l}\text { Sobrecarga do modo ferroviário. } \\
\text { Possivel recurso ao modo } \\
\text { rodoviário para descongestionar }\end{array}$ \\
\hline $\begin{array}{l}\text { Aumento dos preços no } \\
\text { himterland (transporte e } \\
\text { logisticos) }\end{array}$ & $\begin{array}{l}\text { O aumento do preço dos combustiveis e das taxas sobre o modo rodoviário } \\
\text { mcrementam os custos de transporte no hinterland (c. 10\%) }\end{array}$ & $\begin{array}{c}\text { Declinio do transporte terrestre. } \\
\text { Tramsferência modal do } \\
\text { rodoviário para o ferroviário e } \\
\text { para o maríimo }\end{array}$ & $\begin{array}{l}\text { Aumento do tenpo necessário } \\
\text { para a entrega dos bens }\end{array}$ \\
\hline
\end{tabular}

Não obstante uma paridade relativa entre Panamá e Suez, este último continuará sendo o principal ponto estratégico de passagem ao longo da global beltway. Esta análise revela, do ponto de vista geoestratégico e geopolítico, a alta exposição aos eventos políticos e sociais; isto é, a forte vulnerabilidade atual da rede marítima global face à necessidade da passagem do tráfego por estreitos e canais.

\section{O alargamento do canal do Panamá: que resultados para Sines?}

Com o crescimento do tamanho dos navios porta-contentores, que forçam à existência de um menor número de escalas, o porto escolhido pelas companhias marítimas deve apresentar, além de outros fatores, capacidade de absorção do seu hinterland e qualidade e eficiência das conexões intermodais, aspetos que se materializam na forma como os armadores escolhem os portos de escala das suas linhas de serviço.

O Canal do Panamá está atualmente longe de poder influenciar os fluxos mundiais de comércio marítimo devido à limitação da envergadura dos navios que suporta. No entanto, com o alargamento da passagem, as rotas à volta do mundo (round-the-world liner services), serão de novo equacionadas, o que pode fazer renascer essa rede de serviço (Notteboom e Rodrigue, 2009). Em princípio, com a expansão do Canal do Panamá, poderá ocorrer uma paridade relativa entre os canais do Suez e aquele em termos de capacidade. Mas estas expectativas podem ser alvo de alguma contenção fruto de uma menor procura agregada, da tendência pelo "regionalismo" comercial e do aumento do preço dos combustíveis ou da opção por rotas alternativas em detrimento das rotas atuais (Figura 6). 
Figura 6. Rotas alternativas e regionalismo comercial

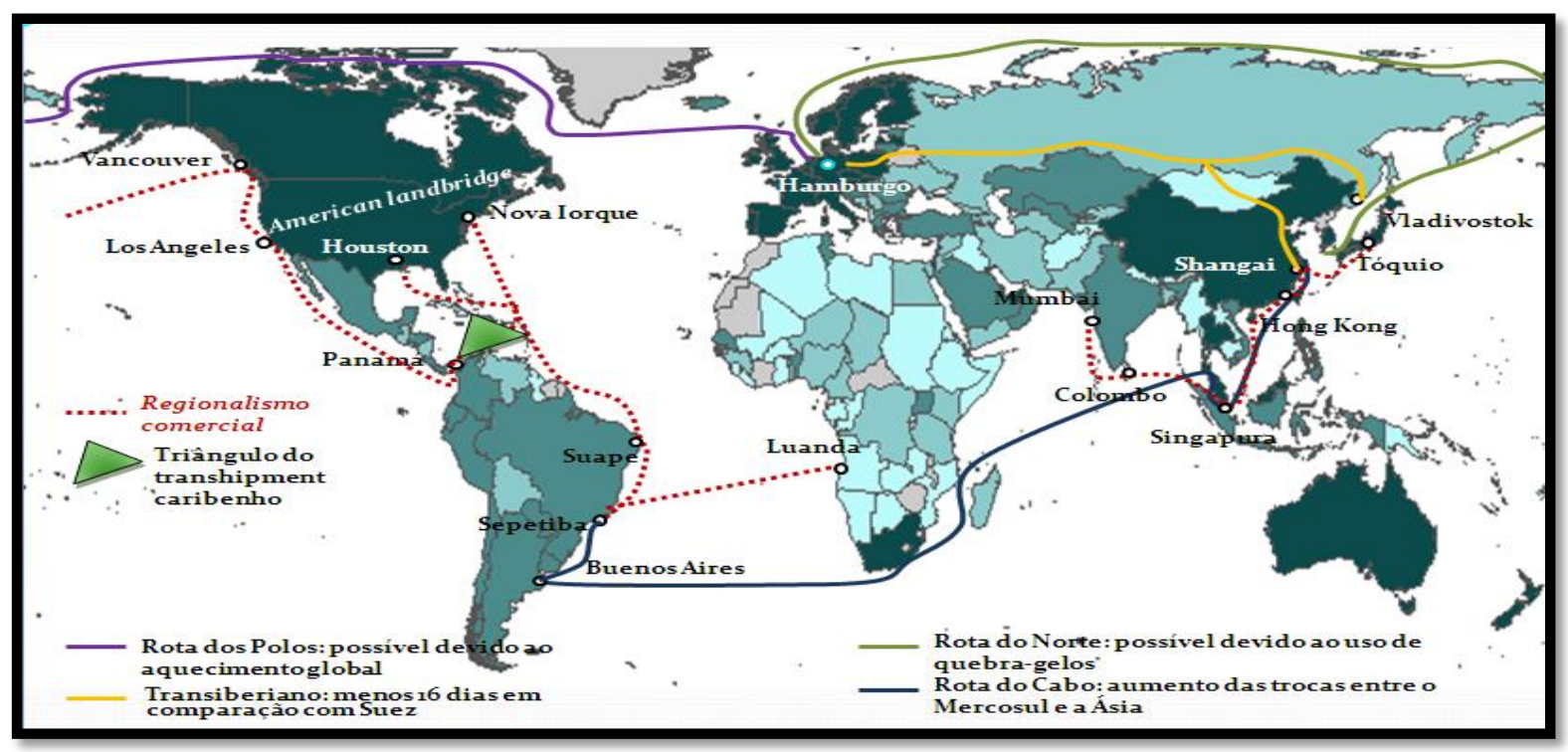

Fonte: Elaboração própria.

Outra questão prende-se com os custos com as tarifas que incidam sobre o tráfego contentorizado em trânsito pelo Canal uma vez que os altos financiamentos do investimento poderão levar a um aumento das taxas praticadas pela PCA, originando a perda de atratividade por aquela passagem ${ }^{8}$.

A isto junta-se o aumento dos preços com o trabalho que se registam já em algumas das economias asiáticas emergentes e que poderão favorecer um comércio mais localizado em detrimento do comércio de longa distância.

\section{Considerações finais para Sines no horizonte 2030}

Com base no Cenário de Crescimento Moderado, as análises de sensibilidade adicionais delineadas mostram que mesmo assim é possível que se assista ao aumento dos fluxos comerciais via Canal do Panamá e que, como opção de redução de custos com o transporte associados ao preço dos combustíveis, as linhas de serviço sejam redefinidas de forma a privilegiar as plataformas de distribuição através do SSS (short-sea shipping). Com o redesenho das redes logísticas de distribuição, o modo rodoviário passa por ser preterido pelo ferroviário, no hinterland competitivo e pelo marítimo no longo curso, surgindo Sines como um porto posicionado na fachada atlântica com fortes possibilidades de ser escolhido como um novo nó da rede marítima global; como hub de transhipment ou, preferencialmente, como gateway - o

\footnotetext{
${ }^{8}$ Em termos de redução do ganho obtido pelos armadores na opção Panamá em detrimento do Suez, a Autoridade do Canal do Panamá aumentou substancialmente as taxas de US\$40 por TEU, em 2006, para US\$72 em 2009, um aumento de $80 \%$. Em 2011, as taxas aumentaram ligeiramente para US\$74 por TEU. Isto significa que os aumentos verificados já capturaram cerca de $40 \%$ do potencial de redução de custos o que faz diminuir uma parte substancial dos ganhos esperados (Rodrigue e Notteboom, in: PTI Journal, edição n. ${ }^{5}$ 52, Nov. 2011).
} 
que poderá ser substantivamente positivo se forem criadas, por parte dos intervenientes na cadeia logística transnacional, redes de suporte em terra para servirem a redistribuição dessas cargas. As suas ligações ferroviárias, o desempenho portuário global e as ações empreendidas para aumentar o nível de competitividade, jogam um papel que fará certamente toda a diferença na obtenção de um maior estatuto ou de menor relevância na hierarquia portuária.

\section{RELATÓRIO FINAL - VISÃO ESTRATÉGICA E GLOBAL; UMA SÍNTESE POSSÍVEL}

\section{O posicionamento geográfico e a cadeia marítima}

A globalização das redes logísticas acentua a importância do relacionamento entre o desenvolvimento do porto com as cadeias mundiais de abastecimento (Notteboom e Winkelmans, 2001) e com o desenvolvimento da região onde se insere (Notteboom e Rodrigue, 2005), porque os portos não competem isoladamente como locais de simples movimentação de carga mas sim como vértices cruciais das cadeias de abastecimento globais (Ducruet e Notteboom, 2010) e o porto de Sines não pode existir dissociado da rede logística de distribuição ao qual pertence. Um porto que seja ao mesmo tempo um gateway assegura um grande domínio nas circulações de carga para o interior. A gestão otimizada desses fluxos no espaço global de distribuição terá que dar atenção particular aos custos, ao tempo e à confiança depositada.

Com o alargamento do Canal do Panamá, a passagem de navios maiores poderá favorecer o posicionamento estratégico de Sines uma vez que as economias de escala que daí advêm irão originar menos portos de escala e a concentração do tráfego em hubs específicos. Convém no entanto ter presente que, tal como a maioria dos portos, Sines está dependente dos seus principais clientes: os armadores, os quais estão na base do processo de atribuição de uma maior ou menor centralidade e de uma maior ou menor importância em termos de hierarquia portuária. A questão da "centralidade" de um porto do ponto de vista da escolha do armador é assunto de grande debate entre os especialistas e passa por ser um tema recorrente quando se estuda Sines como plataforma de redistribuição de carga e da quota de mercado no negócio do transporte contentorizado mundial. Esta posição estratégica é suportada pela perspetiva com que se olha essa centralidade, das preferências globais dos armadores pela minimização dos custos e do que se entende por isso, como Rudel e Taylor (2000: 89) afirmam: “ time advantages on the sea leg do not necessarily imply cost reductions". Para quem confia unicamente na reclassificação de Sines dentro da hierarquia portuária baseado na vantagem aparente dos ganhos com a redução de tempo com a distância, em relação com portos mediterrânicos ou do Norte da Europa, esse é um argumento que cai assim por terra.

DINÂMIA'CET - IUL, Centro de Estudos sobre a Mudança Socioeconómica e o Território 
Se a última palavra pertence aos armadores, na escolha das escalas dos grandes ULCS's, (Ultra Large Container Ship), a não existência de condições apelativas de um porto (que se revelam sob a forma de fatores de competitividade) seja na existência de infraestruturas, de nós logísticos e de ligações fiáveis ao hinterland, reproduzirão esses efeitos repulsivos.

O cerne da força competitiva que Sines apresenta - o da horizontalidade geográfica em comparação com o Panamá -, não é condição suficiente para explicar a sua escolha. A atratividade deste critério apenas hipoteticamente se justifica já que Sines não é uma peça isolada do tabuleiro do xadrez dos fluxos de comércio internacional, o qual, segundo Rodrigue, (2011: 7), obedecem a “(...) physical flows that may not necessarily use the most direct path, but the path of least resistance". Deste modo tem que se olhar para as virtudes e defeitos da cadeia logística e aos aspetos ligados aos diversos níveis de fricção uma vez que a distribuição pretere cada vez mais a distância à confiança do serviço. A fiabilidade respeita aos custos indiretos causados por atrasos ou por estragos ocorridos na movimentação das cargas (Tongzon, 2008) e esta tendência tem crescido de tal forma que, segundo a Maersk, (Newsletter Antwerp Port Authority Volume 14, $N^{\circ}$ 64, Julho 2011, pág. 11), "Reliability is the new price war. Customers don't look for the cheapest price, they look for reliability of services". A competitividade de um porto é acima de tudo produto da eficiência no fornecimento dos serviços pretendidos pelos utilizadores (Brooks e Pallis, 2008:9) e a atratividade é apenas um pré-requisito que permite a um porto ganhar competitividade $(\mathrm{Ng}, 2006)$.

Para que Sines venha a ganhar com um potencial aumento de tráfego e começando por esbater, inter alia, as principais condicionantes enunciadas, a Sines, espartilhado pela exiguidade do seu hinterland, restam duas possibilidades: a primeira, será a de se constituir como elemento potenciador da eclosão de um cluster industrial regional que crie condições para um aumento das exportações e da captação de fluxos de carga do hinterland competitivo, - formas de criar absorção -, constituindo-se num gateway ibérico. A segunda, será constituir-se em simples nó intermédio de transhipment de mercadorias contentorizadas, o que não converte, no médio prazo, o porto em polo dinamizador regional.

\section{A natureza do porto de Sines e a competição direta}

Sines continua sendo um porto muito especializado em granéis líquidos, embora o segmento da carga contentorizada venha a subir gradualmente de importância (Anexo 4). O crescimento deste tipo de carga, no entanto, não foi suficiente para colocar Sines na média do crescimento observado nos portos congéneres, podendo-se afirmar que, na apreciação global, tem vindo a perder terreno face a estes competidores nos últimos dez anos. Mas será necessária alguma contenção na análise destes números: não só se compara um grupo de portos onde constam dois dos principais hubs a nível europeu como a realidade económica dos dois países é

DINÂMIA'CET - IUL, Centro de Estudos sobre a Mudança Socioeconómica e o Território 
razoavelmente distinta. Não deixa de ser impressionante no entanto e, que sirva de cotejo, o crescimento que se verifica em Algeciras e principalmente no porto de Valencia.

Para não subverter o resultado final desta análise convém ter presente que um porto é um cluster de atividades económicas onde um grande número de empresas fornece produtos e serviços e, em conjunto, criam diferentes produtos portuários. Avaliar o desempenho global de um porto a partir de indicadores agregados pode fazer deturpar a avaliação entre portos. O principal indicador do desempenho portuário utilizado pelos portos continua a ser a movimentação de cargas, no entanto existem várias limitações ao seu uso: i) adicionar a movimentação de mercadorias de natureza distinta numa unidade agregada limita o valor de comparação entre portos (uma tonelada de petróleo é diferente de uma tonelada de sumo de fruta); ii) o movimento de cargas não nos diz muito acerca do impacto económico do porto na região onde se insere e, iii) o aumento do volume de cargas pode ser explicado pelos fluxos de comércio internacionais e pouco pelo desempenho do porto (De Langen, Nijdam e Van der Horst, 2007: 24).

Atribuindo-se a dimensão que vários autores dão à necessidade da existência de um portfólio diversificado de cargas, de modo a garantir uma maior flexibilidade operacional e um risco menor perante as oscilações dos preços das matérias-primas, Sines deve prosseguir o caminho de incremento das mercadorias contentorizadas sem perder a sua vocação de porto energético. A recente condição de principal porto exportador nacional deve continuar a ser promovida usando todas as estratégias de marketing portuário, de forma a atrair mais clientes que exportem por via marítima e desse modo, por meio do aumento da procura, ajudar a criar condições ao estabelecimento de mais linhas regulares.

\section{A oferta de transporte}

O desenvolvimento económico está cada vez mais ligado ao desenvolvimento dos transportes. A redução do tempo passou a ser um requisito fundamental desde a expedição do bem, passando pela sua transmissão através da cadeia intermodal, até à entrega ao consumidor final. Os meios de transporte unem os fatores produtivos numa complexa rede de relações entre produtores e consumidores e o resultado é uma mais eficiente divisão da produção através da exploração de vantagens comparativas bem como dos meios para desenvolver economias de escala. A produtividade do espaço, do capital e do trabalho são por isso melhoradas com a eficiência da distribuição. Em termos de economia espacial, a delimitação da fronteira em que Sines compete pelo tráfego no hinterland competitivo obriga ao estudo espacial da localização e da expansão da sua rede de distribuição. Esta expansão deve-se sobretudo ao processo de racionalização e de especialização do tráfego ferroviário, cujo sucesso depende no entanto do aumento da capacidade, da velocidade e da unitização da carga geral via contentor. Deste modo o caminhode-ferro que serve o porto de Sines será o catalisador à fixação de diversos clusters logísticos e

DINÂMIA'CET - IUL, Centro de Estudos sobre a Mudança Socioeconómica e o Território 
industriais de natureza heteróclita, ao longo do corredor que liga o porto às regiões urbanas do interior ou aos polos industriais e ao escoamento célere dos fluxos originados nos hinterland. Unidades produtivas como a futura fábrica da Embraer, localizada na zona de Évora, decerto contribuirão e exigirão, a um mesmo tempo, que a rede ferroviária responda às condições enunciadas. Por força da nossa condição geográfica somos nós que temos que adaptar as nossas ligações ao resto da Europa e em articulação com Espanha, seja através da evolução para a bitola europeia, seja pela harmonização da rede de eletrificação, do reforço da resistência de engates, seja adaptando o sistema de controlo e sinalização do tráfego ferroviário. O que está em jogo é a questão da interoperalidade que permita aos comboios portugueses entrar em Espanha sem dificuldade, como tem sido reclamado por vários agentes económicos.

A existência de um "missing link" pressupõe a necessidade de uma ligação direta de Sines à Plataforma Logística de Badajoz, porta de entrada no hinterland competitivo sem a qual não haverá potencial de crescimento devido à exiguidade do hinterland natural. A ligação dos portos do Sul com a plataforma logística do Poceirão e a partir dessa a Madrid, constituiu até há pouco tempo uma prioridade. Em termos puramente geográficos mas também em termos de agilidade e de economia de transporte, para Sines, este traçado não representa a melhor opção sendo que obriga a uma inflexão dos fluxos de mercadorias demasiadamente a norte, uma verdadeira gincana ferroviária. Esta configuração parece-nos, bem como à APS, constrangedora: a APS entende que deveria ser construída uma ligação de raiz, em linha de alta prestação, em direção a Espanha (entrevista à APS em 14 de Novembro de 2011).

Recentemente, a CE/TEN-T procedeu à reconfiguração daquilo que entende como "core networks", prevendo-se que o eixo de comunicação de Sines a Espanha apresente um traçado que passa por Lisboa (via Poceirão?) e Aveiro. A ligação ao "Corredor Central" (Projeto Prioritário 16, via Badajoz) que lhe permitiria chegar a Madrid no mais curto espaço de tempo ficou adiado para o horizonte 2030. A Plataforma Logística de Badajoz é um nó essencial da ligação de Sines aos fluxos de mercadorias com origem/destino na Extremadura e na Comunidade Autónoma de Madrid, otimizando a competição em relação a Algeciras e ao hinterland ibérico. Tal ligação, a não ocorrer, contribuirá para a perda de competitividade e contraria as economias de escala que se pretendem obter com a constituição de um cluster regional apoiado nas atividades portuárias. Se a política governativa nacional carece de uma praxis para a reestruturação do setor marítimo-portuário, já o governo espanhol, entretanto, formulou e entregou a sua contribuição à CE-TEN-T no atinente aos traçados das novas redes de transportes transeuropeias do seu agrado. Aparentemente, cada governo de modo unilateral, dedica tempo e recursos à elaboração de traçados que não representam decisões comuns coerentes, alimentando ainda mais a confusão que persiste nesta matéria.

DINÂMIA'CET - IUL, Centro de Estudos sobre a Mudança Socioeconómica e o Território ISCTE-IUL - Av. das Forças Armadas, 1649-026 Lisboa, PORTUGAL

Tel. 210464031 - Extensão 293100 E-mail: dinamia@iscte.pt www.dinamiacet.iscte.pt 
Sines como cluster regional: potencialidades e desafios

A filosofia do que se propõe para Sines é algo que nos remete para a realidade de novos clusters marítimos como o de Turku, na Finlândia, mais do que Antuérpia, Roterdão ou Hamburgo, isto por necessidades de adaptação à nossa escala, aos recursos e população. Tomando o exemplo dos clusters finlandeses, não é por acaso que hoje essas regiões apresentam um PIB per capita dos mais elevados do mundo, com taxas de desemprego sofríveis e onde se encontram profissionais de diversas especialidades e de grande qualificação, fruto dos benefícios recolhidos por via do aumento da massa crítica gerada pelo investimento imputado a setores económicos resgatados da inatividade. Estes clusters constituem o modelo ousado do caminho para Sines, algo que representa um verdadeiro desafio à política de investimento, que, pela sua dimensão, ultrapassa a capacidade financeira e a moldura jurídica da APS, o que sugere a sua conceção no âmbito mais estrito da política nacional integrada e sujeito a uma supervisão pombalina.

Se a desmaterialização da economia originou a descontinuação ou a extinção de vários setores produtivos outrora ilustrativos do grau de profissionalização da mão-de-obra e da qualidade da produção nacionais (setores da metalurgia e da metalomecânica: Mague, Somague e Mompor; da construção e da reparação naval: Lisnave, Setenave), aproveitando o progresso tecnológico verificado nos métodos de fabrico, ao nível dos equipamentos, maquinaria e desenvolvimento de ferramentas de suporte computorizado, bem como dos novos métodos de gestão e de otimização da produtividade, deve-se voltar a investir nestas indústrias do secundário tal como sugerido pela CE (http://eur-lex.europa.eu/LexUriServ/LexUriServ.do?uri=COM:2007:0575:FIN:EN:PDF).

Vários países europeus fizeram-no e voltaram a ter indústrias marítimas muito competitivas (as quais impulsionam toda uma variedade de outras incorporadoras de elevado valor e altamente transacionáveis, tais como a eletrónica e mecatrónica). Temos o caso representativo de estaleiros navais finlandeses que ganham concursos para construir os maiores navios de cruzeiro ou os estaleiros alemães de Jade Weser, onde se fabricam plataformas gigantescas de prospeção de petróleo; países em que os custos de trabalho são dos mais elevados do mundo!

Como modo complementar de atração de pessoas e facilitador de mobilidade entre regiões, deve-se desenvolver não apenas as condições ligadas ao ambiente de negócios mas igualmente as do ambiente residencial. Parece claro que os empresários e os quadros técnicos deverão residir nas cidades ou nas suas proximidades procurando-se minimizar as deslocações. Neste aspeto, a região alentejana carece, ainda, de atração em termos residenciais que possam otimizar os efeitos da mobilidade em função do local de trabalho. No entanto, as potencialidades da região, a beleza das paisagens, a qualidade dos recursos piscatórios e das suas praias aliadas ao facto de ser uma zona descongestionada com espaço em abundância, podem criar condições especiais de fixação de uma população escolarizada e de alta qualificação profissional. 
A alteração do paradigma não se cinge apenas a alterações do modelo económico ao qual as nações têm que responder como representa igualmente a deslocação do locus do comércio mundial, à medida que diferentes países ocupam os lugares cimeiros do panorama internacional; é face a esse novo ambiente que as políticas a implantar têm que ser adequadas. No entanto, é essencial que o modelo económico a adotar deva assentar num modelo empresarial mais preocupado com as questões ambientais e com a sustentabilidade de longo prazo.

Aumentar a competitividade de Sines passará por focalizar a atenção na constituição de uma "marca" mas igualmente através do marketing de "localização", para fazer reconhecer toda a região como zona sensível de ações integradas. Esse tipo de ações poderia ser um dos objetivos tácitos da recentemente formada Comunidade Portuária de Sines (CPSI), no entanto, e um pouco inexplicavelmente, a APS não faz parte desta comunidade. Deverá apostar-se igualmente na notoriedade e na visibilidade do porto e da Zona Industrial e Logística e deverá sobretudo ser cultivada e assegurada a imagem de confiança na cadeia de abastecimento.

O plano de marketing do porto de Sines deverá ser uma extensão natural do plano estratégico e terá como finalidade promover a estratégia da APS em atrair novos clientes e para as indústrias residentes promoverem os seus negócios, procurando a satisfação das necessidades dos clientes atuais e potenciais em todas as relações inerentes e complementares. O plano de marketing permite detetar as oportunidades, ameaças, pontos fortes e fracos, permite promover a gestão por objetivos, basear a tomada de decisão, a fixação de metas, quantifica desvios e a sua correção com o processo, a quantificação de resultados, uma menor possibilidade de ocorrência de insucesso, mecanismos de controlo e otimização de recursos e de resultados.

A partir da análise de contexto (oportunidades e ameaças) e da análise do porto de Sines (pontos fortes e fraquezas), foram formuladas as seguintes estratégias de marketing, assentes numa Análise SWOT (Quadro 7).

Quadro 7: Análise SWOT.

\begin{tabular}{|c|c|c|c|}
\hline \multicolumn{2}{|r|}{ Strenghts (Forças) } & \multicolumn{2}{|r|}{ Weaknesses (Fraquezas) } \\
\hline 1 & $\begin{array}{l}\text { Um dos portos europeus que } \\
\text { apresenta melhores condições de acessibihidade por mar }\end{array}$ & 1 & Fraca captação de tráfego hinterland e incịiente ligação ferroviária a Espanha \\
\hline 2 & $\begin{array}{l}\text { Situação geoestratégica } \\
\text { privilegiada face às principais rotas marítimas }\end{array}$ & 2 & $\begin{array}{l}\text { Afastamento em relação aos principais pólos de prodıção e consumo a nivel } \\
\text { nacionalibérico }\end{array}$ \\
\hline 3 & $\begin{array}{l}\text { Capacidade portúária (porto de águas profundas) e espaço adjacente } \\
\text { pronto para a fixação de empresas logísticas e industriais }\end{array}$ & \multirow{2}{*}{3} & $\begin{array}{l}\text { Grande dependência da MSC e de risco de deslocalização da atridade deste } \\
\text { armador }\end{array}$ \\
\hline 4 & Aprofundamento de lógicas de especiafização e "chusterização" & & $\begin{array}{l}\text { Muito fraca densidade económica (sobretudo industrial) e demográfica da } \\
\text { região onde se situa, bem como fraca intensidade em traballo das actividades } \\
\text { instaladas }\end{array}$ \\
\hline \multicolumn{2}{|r|}{ Opportunities (Oportunidades) } & \multicolumn{2}{|r|}{ Threats (Ameaças) } \\
\hline 1 & Atracção de grandes e médias empresas (valor económico) & 1 & Hubs do Norte da Europa \\
\hline 2 & Novas induistrias de alto vabor acrescentado & 2 & Hubs do Mediterrâneo Ocidental \\
\hline 3 & Atração de IDE & 3 & Hubs do Mediterrâneo Oriental \\
\hline 4 & Aumento das exportações por via maritma & 4 & Suspensão do Projeto Prioritário n. ${ }^{\circ} 16$ \\
\hline 5 & Atração de cargas após alargamento do Canal do Panamá & 5 & Perigo de grave acidente em mar, no porto, nos gasodutos ou no oleoduto \\
\hline 6 & Regionalização portuária do hinterland & 6 & Contração do PIB nacional \\
\hline 7 & Estabelecimento de um porto hub \& spoke & 7 & Contração dos fluxos de comércio mundiais \\
\hline
\end{tabular}

Fonte: Elaboração própria.

DINÂMIA'CET - IUL, Centro de Estudos sobre a Mudança Socioeconómica e o Território 
Por fim, cumpre ressalvar que, no âmbito do processo de constituição de um cluster de excelência, as potencialidades turísticas e o ambiente residencial deverão ser promovidos a par da marca Sines de modo que esta não se torne sinónimo redutor de área industrial, logo criador de forças de repulsão.

Tornar Sines (Sines como mega região, não se confinando à área de intervenção portuária), um verdadeiro polo de desenvolvimento, um cluster regional acolhedor de empresas e de I\&D, passa por uma ação mais interventiva da APS em conjugação com outras forças políticas e sociais, privadas e públicas, (um novo GAS com atribuições multidimensionais e competências pluri-regionais?). Para que tal seja exequível são necessários investimentos, isto numa altura adversa à sua realização mas talvez aquela em que tal ocorrência se torna mais premente e propiciadora de grande impacto na estrutura socioeconómica regional.

Agora que tanto se fala de economia do mar, seria talvez interessante falar de investimentos na área da exploração dos recursos minerais e haliêuticos, da piscicultura e da algacultura, de agroturismo e de enoturismo, de indústrias de captura e armazenamento de $\mathrm{CO} 2$, de indústrias "verdes" de reaproveitamento e reciclagem de materiais, de centrais de dessalinização e respetivas estações de bombagem e ramais de transporte de água, isto quando os efeitos de seca severa que ameaçam todo o país tendem a ser perenes. Investimentos macro estruturantes deste tipo - para citar apenas alguns exemplos - certamente alterariam o tecido industrial e a qualificação da força de trabalho regional contribuindo para a implementação de algumas indústrias de charneira e que constituem exemplos de investimentos coerentes e inovadores. Coerentes pois recorrem ao aproveitamento dos recursos naturais, inovadores porque representam desenvolvimento industrial, promoção de novos modelos de negócio, aumento da capacidade tecnológica e um estímulo à competitividade e à criação de postos de trabalho qualificados.

\section{Os "novos" players: o Brasil, o Mercosul e a China}

No que respeita ao comércio marítimo com os emergentes e atendendo ao agigantar das potencialidades desses mercados no conjunto das trocas comerciais inter/nacionais, deve ser dada a devida atenção em cenário antecipador ao contrário de uma resposta retroativa. Sines não pode neste desafio remeter-se a um papel secundário (que poderá inclusivamente condicionar toda a capacidade futura de crescimento) e ficar resumido ao seu hinterland natural mas sim estabelecer uma pluralidade de formas de negócio a nível regional e até supranacional, o que vem ao encontro do que Notteboom (2012) afirmou recentemente: "o futuro dos portos não depende apenas dos fluxos de comércio esperados mas sim onde e em que condições esses fluxos se moverão globalmente, vistos na perspetiva da rede de distribuição". 
Segundo a APS, o tráfego de mercadorias entre o Porto de Sines e o Brasil tem vindo a crescer nos últimos anos na área dos produtos petrolíferos, tendo este país em 2010 atingido a 4. ${ }^{\mathrm{a}}$ posição no fornecimento de crude para a Refinaria de Sines e em 2011 foi o país com o maior índice de crescimento no tráfego de contentores. Em 2011 observou-se um crescimento homólogo das exportações em 8\%, constando o Brasil como um dos principais novos destinos para as mercadorias. Ainda em 2011 foi estabelecido um serviço regular da MSC que liga semanalmente Sines à América do Sul. Com este novo serviço regista-se um incremento no crescimento das trocas comerciais com o Brasil, quer no mercado das exportações quer no das importações. Em Janeiro de 2012 a MSC inaugurou um novo serviço regular que liga Sines a portos do Brasil, Uruguai e Argentina o que faz prever um novo impulso nas trocas não apenas com o Brasil mas com todo o Mercosul. Ainda no primeiro trimestre de 2012 a CMA- CGM, o terceiro grande operador mundial, passou a ligar Sines a África através de um serviço regular que serve portos da costa ocidental mas que poderá ser alargado a outros destinos.

A existência de linhas regulares implicam a predeterminação de horários, portos de origem e destino, fretes pré-estabelecidos e a integração com cadeias de transporte terrestre e marítimo. A escala de um porto por maior número de linhas regulares é potenciador de atração de mais cargas elevando o desempenho e os níveis de eficiência do porto, que pode planear as escalas, minimizar tempos de espera e custos oferecendo uma maior gama de destinos a custos inferiores e com baixos transit times (Caldeirinha, 2010:36). Por outro lado, as companhias marítimas ao estabelecerem linhas regulares, valorizam toda uma gama de serviços marítimos como a reparação naval, o que pode constituir um incentivo ao estabelecimento de tais serviços (Notteboom, 2012). As linhas regulares que escalam Sines são ainda em número diminuto quando em comparação com as que servem os portos espanhóis, como se poderá verificar no Quadro 1 acima.

Quanto à China, as nossas exportações têm crescido bastante mas ainda estamos longe de falar em paridade. A China apresenta uma quota crescente no movimento internacional de trocas comerciais (tanto em termos absolutos e relativos), mas os fluxos de comércio trans-Pacífico estão a crescer mais rapidamente que o transoceânico, o que poderá indiciar possíveis alterações tornando-se o tráfego mais "localizado". O investimento chinês em Portugal passou a ser assunto de grande debate com a recente compra das ações privilegiadas que o Estado detinha na EDP e na REN. Deste modo terá porventura chegado a altura de começar a trabalhar na atração de investimento direto desse país para a região de Sines - localizado no porto ou no seu hinterland?

DINÂMIA'CET - IUL, Centro de Estudos sobre a Mudança Socioeconómica e o Território 


\section{BIBLIOGRAFIA}

Aronietis, R. et al. (2010), Some Effects of Hinterland Infrastructure Pricing on Port Competitiveness: case of Antwerp, 12th WCTR, July 11-15, 2010 - Lisbon, Portugal.

Brooks, M.R. e Pallis, A.A. (2008), Assessing port governance models: Process and performance components. Maritime Policy and Management, 35(4), pp. 411-432.

Brooks, M.R, Schellinck, T. e Pallis, A.A. (2011), A systematic approach for evaluating port effectiveness. Maritime Policy and Management, vol. 38, n. ${ }^{\circ}$ 3, pp. 315-334. Commercial Deployment of Transportation Technologies:

http://aapa.files.cms- plus.com/SeminarPresentations/07_OPSAFIT_Beckett_Jeanne.pdf.

Caldeirinha, V. (2010), A Influência dos Factores Caracterizadores dos Portos no Desempenho, Tese de Mestrado, MBA-ISEG/UTL.

Cullinane, K. e Wang, Y. (2012), The hierarchical configuration of the container portindustry: an application of multiple linkage analysis, Maritime Policy \& Management.

De Langen, P., Nijdam, M. e Van der Horst, M. (2007), New indicators to measure port performance, Journal of Maritime Research, Vol. IV, n. ${ }^{\circ}$ 1, pp. 23-36, 2007. ISSN: 1697-4840.

Ducruet, C., e Notteboom, T. (2010), The Worldwide Maritime Network of Container Shipping: Spacial Structure and Regional Dynamics, GaWC Research Bulletin, 364. http://www.lboro.ac.uk/gawc/rb/rb364.html.

Ducruet, C. e Notteboom, T. (2012), The worldwide maritime network of container shipping: spatial structure and regional dynamics, Global Networks, doi:10.1111/j.14710374.2011.00355.x, www.porteconomics.eu.

Ducruet, C., Koster, H. e Van Der Beek, D. (2010) Commodity variety and seaport performance, Published in Regional Studies (DOI: 10.1080/00343400903167904), http://halshs.archivesouvertes.fr/docs/00/45/85/96/PDF/Regional_Studies.pdf

Goss, R. (1990), Economic policies and seaports: The Economic Functions of Seaports. Maritime Policy and Management 17, $\mathrm{N}^{\circ} 3$.

DINÂMIA'CET - IUL, Centro de Estudos sobre a Mudança Socioeconómica e o Território 
Meersman H., Van de Voorde, E. e Vanelslander T. (2002), Port Pricing Issues: Considerations on Economic Principles, Competition and Wishful Thinking. University of Antwerp (UFSIARUCA and ITMMA). Papers. Brussels, 14th/15th May.

Merk, O. et al. (2011), The Competitiveness of Global Port-Cities: the Case of the Seine Axis (Le Havre, Rouen, Paris, Caen) - France, OECD Regional Development Working Papers, 2011/07, OECD Publishing. http://dx.doi.org/10.1787/5kg58xppgc0n-en.

NEA et al. (2010), Ports and their connections within the TEN-T - Final Report, Vigie Fiche 394-1, B1. TREN/R1/350-2008 Lot 2.

Ng, K. e Pallis, A.A. (2010), Port governance reforms in diversified institutional frameworks: Generic solutions, implementation asymmetries. Environment and Planning A, vol. 42, n. ${ }^{\circ}$, pp 2147-2167.

Notteboom, T. (2012), Global economic and trade trends: game changer for ports?. http://www.porteconomics.eu/downloads-section/cat_view/22-invitedpresentations.html?orderby=dmdate_published.

Notteboom, T., e Rodrigue, J-P. (2005), Port regionalization: towards a new phase in port development. Maritime Policy and Management, 32(3), 297-313.

Notteboom, T. e Rodrigue, J-P. (2009), Challenges to and challengers of the Suez Canal, http://people.hofstra.edu/jean-paul_rodrigue/downloads/PT51-11_2.pdf.

Notteboom, T. e Winkelmans, W. (2001), Structural changes in logistics: how will port authorities face the challenge?, Maritime Policy and Management 28(1), pp. 71-89.

OCDE, (2010), “ Maddison's forecast revisited: What will the World look like in 2030?”, published by Andrew Mold, Head Finance of Development Unit, (http://www.voxeu.org/index.php?q=node/5708),

Rodrigue, J-P. (2012), Supply Chain Management, Logístics Changes and the Concept of Friction. Chapter 4. For Hall and M. Hesse (eds) (2012) Cities, Regions and Flow, London: Routledge,http://people.hofstra.edu/jeanpaul_rodrigue/downloads/Chapter\%204\%20Supply\%20 Chain\%20Management_Rodrigue.pdf.

Rodrigue, J-P., Comtois, C. e Slack, B. (2006), The Geography of Transport Systems, Routledge, New York.

DINÂMIA'CET - IUL, Centro de Estudos sobre a Mudança Socioeconómica e o Território 
Rodrigue, J-P., Comtois, C. e Slack, B. (2009), The Geography of Transport Systems, Second

Edition, Routledge, New York, http://people.hofstra.edu/geotrans/eng/ch1en/appl1en/ch1a2en.html.

Rudel, R. e Taylor, J. (2000), European sea Transport and Intermodalism - Consequences for Switzerland, Project B8 of the National Research Programme (NRP).

Tovar, B., Trujillo, L. e Jara-Díaz, S. (2004), Organization and regulation of the port industry: Europe and Spain, http://www.cec.uchile.cl/ dicidet/sjara/OrganizationAndRegulation.pdf.

Verhoeven, P. (2009), A Review of Port Authority Functions: Towards a Renaissance?, IAMEFinal 18/05/09 (Paper 2-34), http://www.bpoports.com/assets/files/2- 34\%20paper.pdf.

TEN-T, http://ec.europa.eu/transport/infrastructure/index_en.htm.

The World Bank (2007), Port Reform Toolkit, Alternative Port Management Structures and Ownership Models. DOI: 10.1596/978-0-8213-6607-3.

Tongzon, J. (2008) Port choice and freight forwarders, Transportation Research Part E, Elsevier, http://202.114.89.60/resource/pdf/1850.pdf.

Tongzon, J. e Heng, W. (2005), Port privatization, efficiency and competitiveness: Some empirical evidence from container ports (terminals), Transportation Research Part A 39 (2005) 405-424, http://202.114.89.60/resource/pdf/2024.pdf.

Verhoeven, P. (2011), European Port Governance - Report of an enquiry into the current governance of european seaports.

http://portosdeportugal.pt/UserFiles/espofactfindingreport2010.pdf.

Vitsounis, T. (2009), An economic and legal analysis of the fators determining the competitiveness of ports. Port Economics, http://www.porteconomics.eu.

Wilsmeier, G. e Notteboom, T. (2010), Determinants of liner shipping network configuration : a two region comparison. Proceedings of the 2009 International Association of Maritime Economists (IAME) Conference, June, Copenhagen, Denmark.

Zondag, B. et al. (2008), A model for maritime freight flows, port competition and hinterland transport. European Transport Conference, http://www.etcproceedings.org/paper/a-model-formaritime-freight-flows-port-competition-and-hinterland-transport.

DINÂMIA'CET - IUL, Centro de Estudos sobre a Mudança Socioeconómica e o Território 


\section{ANEXOS}

ANEXO 1. Função de produtividade dos terminais de contentores.

\begin{tabular}{|l|r|r|r|r|r|r|r|r|}
\hline Variáveis & Alge ciras & Barcelona & Bilbao & Sines & Valência & Totais & Média & SD \\
\hline & & & & & & & & \\
Y (total TEU) & 3.602 .631 & 2.034 .000 & 572.784 & 447.495 & 4.202 .152 & 10.859 .062 & 2.171 .812 & 1.711 .628 \\
$\mathbf{X}_{1}$ (n. ${ }^{\circ}$ terminais) & 2 & 2 & 2 & 1 & 1 & 8 & 2 & 0,55 \\
$\mathbf{X}_{2}$ (metros cais) & 4.170 & 3.000 & 4.200 & 940 & 4.000 & 16.310 & 3.262 & 1.388 \\
$\mathbf{X}_{3}$ (n ${ }^{\circ}$ pórticos) & 19 & 17 & 10 & 4 & 13 & 63 & 13 & 5,94 \\
\hline
\end{tabular}

\begin{tabular}{|c|c|c|c|c|c|c|}
\cline { 2 - 7 } \multicolumn{1}{c|}{} & $\mathbf{X}_{1}$ & $\mathbf{X}_{2}$ & $\mathbf{X}_{3}$ & Média & $\Delta$ real/potencial & Pontuação \\
\hline Algeciras & 2.171 .812 & 2.776 .350 & 3.174 .187 & 2.707 .450 & $33 \%$ & 4 \\
Barcelona & 2.171 .812 & 1.997 .374 & 2.840 .081 & 2.336 .422 & $-13 \%$ & 3 \\
Bilbao & 2.171 .812 & 2.796 .324 & 1.670 .624 & 2.212 .920 & $-74 \%$ & 1 \\
Sines & 1.085 .906 & 625.884 & 668.249 & 793.346 & $-44 \%$ & 2 \\
Valência & 1.085 .906 & 2.663 .166 & 3.174 .186 & 2.307 .753 & $82 \%$ & 5 \\
\hline
\end{tabular}

ANEXO 2. Coeficientes de Gini do port range B-B (2010).

Coeficiente de Gini - Distribuição de Cargas (ALGECIRAS - 2010)

\begin{tabular}{|c|c|c|c|c|c|c|c|c|c|}
\hline Distribuiç̆o & $\begin{array}{l}{ }^{000} \text { 'Ton. } \\
\text { (n) }\end{array}$ & Quota \%(n) & $\begin{array}{l}\text { Cargas Totais } \\
(\mathbf{x})\end{array}$ & $\begin{array}{l}\text { Cargas } \\
\text { Acum. (M) }\end{array}$ & $\begin{array}{l}\text { Quota Acum. \% } \\
(x)\end{array}$ & $|x-Y|$ & $x_{a<1}-x_{k}(A)$ & $\gamma_{k=1}+\gamma_{k}(B)$ & $A * B$ \\
\hline Outros GS & 4 & $0 \%$ & $10 \%$ & $0 \%$ & $10 \%$ & $10 \%$ & $10 \%$ & $\infty \%$ & $0 \%$ \\
\hline Minério & 13 & $\%$ & $10 \%$ & $\infty \%$ & $20 \%$ & $10 \%$ & $30 \%$ & $\infty$ & $\infty \%$ \\
\hline Agricolas & 472 & $1 \%$ & $10 \%$ & $1 \%$ & $30 \%$ & $99 \%$ & $50 \%$ & $1 \%$ & $\infty \%$ \\
\hline Carvăo & 986 & $1 \%$ & $10 \%$ & $2 \%$ & $40 \%$ & $9 \%$ & $70 \%$ & $1 \%$ & $1 \%$ \\
\hline Gases e Liquefertos & 1265 & $2 \%$ & $10 \%$ & $4 \%$ & $50 \%$ & $8 \%$ & $90 \%$ & $2 \%$ & $2 \%$ \\
\hline Ro-ro & 4.96 & $\%$ & $10 \%$ & $10 \%$ & $60 \%$ & $4 \%$ & $110 \%$ & $6 \%$ & $\pi \%$ \\
\hline Fraccionada & 4567 & $7 \%$ & $10 \%$ & $10 \%$ & $70 \%$ & $3 \%$ & $130 \%$ & $7 \%$ & $8 \%$ \\
\hline Refinados & 7246 & $10 \%$ & $10 \%$ & $27 \%$ & $80 \%$ & $0 \%$ & $150 \%$ & $10 \%$ & $15 \%$ \\
\hline Petróleo & 15383 & $22 \%$ & $10 \%$ & $49 \%$ & $90 \%$ & $12 \%$ & $170 \%$ & $22 \%$ & $3 \%$ \\
\hline Contentores & 36063 & $51 \%$ & $10 \%$ & $100 \%$ & $100 \%$ & $41 \%$ & $190 \%$ & $51 \%$ & $98 \%$ \\
\hline & 70.195 & $100 \%$ & $100 \%$ & & & $107 \%$ & & & $106 \%$ \\
\hline
\end{tabular}
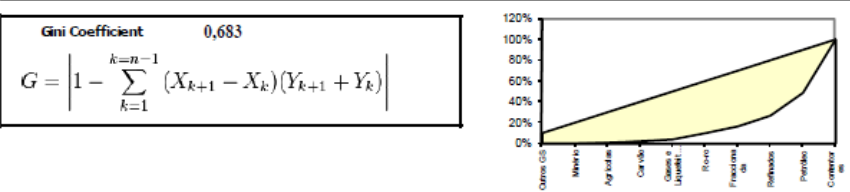

Coeficiente de Gini - Distribuição de Cargas (BARCELONA - 2010)

\begin{tabular}{|c|c|c|c|c|c|c|c|c|c|}
\hline Distribuiç̧o & ${ }_{(m)}^{000}$ 'Ton. & Quota \%(n) & $\begin{array}{l}\text { Cargas Totais } \\
(x)\end{array}$ & 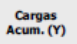 & $\begin{array}{l}\text { Quota Acum. \% } \\
(x)\end{array}$ & $|x-y|$ & $x a+1-x_{k}(A)$ & $\eta_{k+1}+\gamma_{k}(B)$ & $A * B$ \\
\hline Petroleo & 1 & $\%$ & $10 \%$ & $\infty \%$ & $10 \%$ & $10 \%$ & $10 \%$ & $\infty \%$ & $\%$ \\
\hline Carvăo & 186 & $\%$ & $10 \%$ & $0 \%$ & $20 \%$ & $10 \%$ & $30 \%$ & $\infty \%$ & $0 \%$ \\
\hline Minerio & 657 & $2 \%$ & $10 \%$ & $2 \%$ & $30 \%$ & $8 \%$ & $50 \%$ & $2 \%$ & $1 \%$ \\
\hline Agricolas & 1327 & $3 \%$ & $10 \%$ & $59 \%$ & $40 \%$ & $7 \%$ & $70 \%$ & $3 \%$ & $2 \%$ \\
\hline Outros GS & 1372 & $3 \%$ & $10 \%$ & $9 \%$ & $50 \%$ & $7 \%$ & $90 \% \%$ & $3 \%$ & $3 \%$ \\
\hline Refinados & 4900 & $12 \%$ & $10 \%$ & $21 \%$ & $60 \%$ & 29 & $110 \%$ & $12 \%$ & $14 \%$ \\
\hline Gases e Liquefeitos & 6.657 & $17 \%$ & $10 \%$ & $38 \%$ & $70 \%$ & $7 \%$ & $130 \%$ & $17 \%$ & $22 \%$ \\
\hline Ro-ro & 8050 & $20 \%$ & $10 \%$ & $58 \%$ & $80 \%$ & $10 \%$ & $150 \%$ & $20 \%$ & $30 \%$ \\
\hline Fraccionada & 8589 & $22 \%$ & $10 \%$ & $80 \%$ & $90 \%$ & $12 \%$ & $170 \%$ & $22 \%$ & $3 \%$ \\
\hline \multirow[t]{2}{*}{ Contentores } & 8050 & $20 \%$ & $10 \%$ & $100 \%$ & $100 \%$ & $10 \%$ & $190 \%$ & $20 \%$ & $38 \%$ \\
\hline & 39.729 & $100 \%$ & $100 \%$ & & & $82 \%$ & & & $147 \%$ \\
\hline
\end{tabular}

\begin{tabular}{l}
\hline Gini Coefficient 0,472 \\
$G=\left|1-\sum_{k=1}^{k=n-1}\left(X_{k+1}-X_{k}\right)\left(Y_{k+1}+Y_{k}\right)\right|$
\end{tabular}

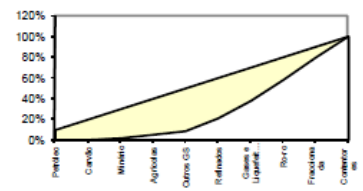

DINÂMIA'CET - IUL, Centro de Estudos sobre a Mudança Socioeconómica e o Território 
O Contributo de Sines na Eclosão de um Cluster Regional

Coeficiente de Gini - Distribuição de Cargas (BILBAO - 2010)

\begin{tabular}{|c|c|c|c|c|c|c|c|c|c|}
\hline Distribuiç̧o & $\begin{array}{l}{ }^{000} \text { 'Ton. } \\
(n)\end{array}$ & Quota \% (n) & $\begin{array}{l}\text { Cargas Totais } \\
(x)\end{array}$ & $\begin{array}{l}\text { Cargas } \\
\text { Acum. (M) }\end{array}$ & $\begin{array}{l}\text { Quota Acum. \% } \\
\qquad(x)\end{array}$ & $|x-y|$ & $x a+1-x_{k}(A)$ & $\eta_{k=1}+\eta_{k}(B)$ & $A^{*} B$ \\
\hline Agricolas & 262 & $1 \%$ & $10 \%$ & $1 \%$ & $10 \%$ & $9 \%$ & $10 \%$ & $1 \%$ & $0 \%$ \\
\hline Carvăo & 681 & $2 \%$ & $10 \%$ & $3 \%$ & $20 \%$ & $8 \%$ & $30 \%$ & $2 \%$ & $1 \%$ \\
\hline Ro-ro & 930 & $3 \%$ & $10 \%$ & $5 \%$ & $30 \%$ & $7 \%$ & $50 \%$ & $3 \%$ & $1 \%$ \\
\hline Minério & 964 & $3 \%$ & $10 \%$ & $8 \%$ & $40 \%$ & $7 \%$ & $70 \%$ & $3 \%$ & 29 \\
\hline Outros GS & 2544 & $7 \%$ & $10 \%$ & $16 \%$ & $50 \%$ & $3 \%$ & $90 \%$ & $7 \%$ & $7 \%$ \\
\hline Fraccionada & 3.750 & $11 \%$ & $10 \%$ & $28 \%$ & $60 \%$ & $1 \%$ & $110 \%$ & $11 \%$ & $12 \%$ \\
\hline Gases e Liquefeitos & 4.112 & $12 \%$ & $10 \%$ & $38 \%$ & $70 \%$ & $2 \%$ & $130 \%$ & $12 \%$ & $15 \%$ \\
\hline Contentores & 5.605 & $18 \%$ & $10 \%$ & $55 \%$ & $80 \%$ & $6 \%$ & $150 \%$ & $16 \%$ & $25 \%$ \\
\hline Petróleo & 7.075 & $20 \%$ & $10 \%$ & $75 \%$ & $90 \%$ & $10 \%$ & $170 \%$ & $20 \%$ & $35 \%$ \\
\hline \multirow[t]{2}{*}{ Refinados } & 8575 & $29 \%$ & $10 \%$ & $100 \%$ & $100 \%$ & $19 \%$ & $190 \%$ & $25 \%$ & $47 \%$ \\
\hline & 34588 & $100 \%$ & $100 \%$ & & & $60 \%$ & & & $145 \%$ \\
\hline
\end{tabular}

$G=\left|1-\sum_{k=1}^{k=n-1}\left(X_{k+1}-X_{k}\right)\left(Y_{k+1}+Y_{k}\right)\right| \mid$

Coeficiente de Gini - Distribuição de Cargas (SINES - 2010)

\begin{tabular}{|c|c|c|c|c|c|c|c|c|c|}
\hline Distribuiç̧o & $\begin{array}{l}{ }^{000} \text { 'Ton. } \\
(n)\end{array}$ & Quota \%(n) & $\begin{array}{l}\text { Cargas Totais } \\
(x)\end{array}$ & $\begin{array}{c}\text { Cargas } \\
\text { Acum. (n) }\end{array}$ & $\begin{array}{l}\text { Quota Acum. \% } \\
\qquad(x)\end{array}$ & $|x-Y|$ & $x_{a+1}-x_{k}(A)$ & $\gamma_{k=1}+\gamma_{k}(B)$ & $A^{*} B$ \\
\hline Ro-ro & 0 & $\%$ & $10 \%$ & $\infty \%$ & $10 \%$ & $10 \%$ & $10 \%$ & $\infty \%$ & $\infty \%$ \\
\hline Agricolas & 3 & $\%$ & $10 \%$ & $\infty \%$ & $20 \%$ & $10 \%$ & $30 \%$ & $\infty$ & $\infty \%$ \\
\hline Minerio & 4 & $\infty \%$ & $10 \%$ & $0 \%$ & $30 \%$ & $10 \%$ & $50 \%$ & $\infty \%$ & $\infty$ \\
\hline Fraccionada & $n$ & $\%$ & $10 \%$ & $\%$ & $40 \%$ & $10 \%$ & $70 \%$ & $\infty \%$ & $\infty \%$ \\
\hline Outros Gs & 200 & $1 \%$ & $10 \%$ & $1 \%$ & $50 \%$ & $9 \%$ & $90 \%$ & $1 \%$ & $1 \%$ \\
\hline Gases e Liquefeitos & 389 & $2 \%$ & $10 \%$ & $3 \%$ & $60 \%$ & $8 \%$ & $110 \%$ & $2 \%$ & $2 \%$ \\
\hline Carvằo & 2789 & $11 \%$ & $10 \%$ & $19 \% \%$ & $70 \%$ & $1 \%$ & $130 \%$ & $11 \%$ & $14 \%$ \\
\hline Contentores & 4.410 & $17 \%$ & $10 \%$ & $31 \%$ & $80 \%$ & $7 \%$ & $150 \%$ & $17 \%$ & $20 \%$ \\
\hline Petróleo & 8.194 & $32 \%$ & $10 \%$ & $63 \%$ & $90 \%$ & $22 \%$ & $170 \%$ & $32 \%$ & $55 \%$ \\
\hline \multirow[t]{2}{*}{ Refinados } & 9.446 & $37 \%$ & $10 \%$ & $100 \%$ & $100 \%$ & $27 \%$ & $190 \% \%$ & $37 \%$ & $70 \%$ \\
\hline & 25512 & $100 \%$ & $100 \%$ & & & $115 \%$ & & & $168 \%$ \\
\hline
\end{tabular}

$$
G=\left|1-\sum_{k=1}^{k=n-1}\left(X_{k+1}-X_{k}\right)\left(Y_{k+1}+Y_{k}\right)\right|
$$

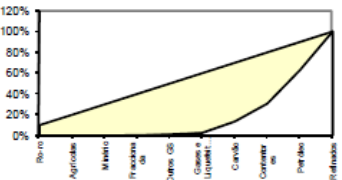

Coeficiente de Gini - Distribuição de Cargas (VALENCIA - 2010)

\begin{tabular}{|c|c|c|c|c|c|c|c|c|c|}
\hline Distribuiçăo & $\begin{array}{l}000 \text { 'Ton. } \\
(n)\end{array}$ & Quota $\%(n)$ & $\begin{array}{l}\text { Cargas Totais } \\
(x)\end{array}$ & $\begin{array}{c}\text { Cargas } \\
\text { Acum. (n) }\end{array}$ & $\begin{array}{l}\text { Quota Acum. \% } \\
\text { (x) }\end{array}$ & $|x-y|$ & $x a+1-x_{k}(A)$ & $\gamma_{k=1}+\gamma_{k}(B)$ & $A * B$ \\
\hline Petróleo & 1 & $\infty \%$ & $10 \%$ & $\%$ & $10 \%$ & $10 \%$ & $10 \%$ & $\infty \%$ & $\%$ \\
\hline Outros GS & 148 & $\infty \%$ & $10 \%$ & $\infty \%$ & $20 \%$ & $10 \%$ & $30 \%$ & $\infty \%$ & $\%$ \\
\hline Carvăo & 194 & $\infty \%$ & $10 \%$ & $1 \%$ & $30 \%$ & $10 \%$ & $50 \%$ & $\infty \%$ & $\%$ \\
\hline Refinados & 844 & $1 \%$ & $10 \%$ & $2 \%$ & $40 \%$ & $9 \%$ & $70 \%$ & $1 \%$ & $1 \%$ \\
\hline Agricolas & 882 & $1 \%$ & $10 \%$ & $3 \%$ & $50 \%$ & $9 \%$ & $90 \%$ & $1 \%$ & $1 \%$ \\
\hline Minério & 1367 & $2 \%$ & $10 \%$ & $5 \%$ & $60 \%$ & $8 \%$ & $110 \%$ & $2 \%$ & $2 \%$ \\
\hline Gases e Liquefeitos & 4.325 & $\% \%$ & $10 \%$ & $11 \%$ & $70 \%$ & $4 \%$ & $130 \%$ & $6 \%$ & $8 \%$ \\
\hline Ro-ro & 4555 & $\%$ & $10 \%$ & $18 \%$ & $80 \%$ & $3 \%$ & $150 \%$ & $7 \%$ & $10 \%$ \\
\hline Fraccionada & 6949 & $10 \%$ & $10 \%$ & $28 \%$ & $90 \%$ & $\%$ & $170 \%$ & $10 \%$ & $17 \%$ \\
\hline \multirow[t]{2}{*}{ Contentores } & 49.028 & $72 \%$ & $10 \%$ & $100 \%$ & $100 \%$ & $6 \%$ & $190 \%$ & $72 \%$ & $136 \%$ \\
\hline & 68204 & $100 \%$ & $100 \%$ & & & $124 \%$ & & & $176 \%$ \\
\hline
\end{tabular}

$$
\begin{aligned}
& \text { Gni Coefficient } 0,764 \\
& G=\left|1-\sum_{k=1}^{k=n-1}\left(X_{k+1}-X_{k}\right)\left(Y_{k+1}+Y_{k}\right)\right|
\end{aligned}
$$

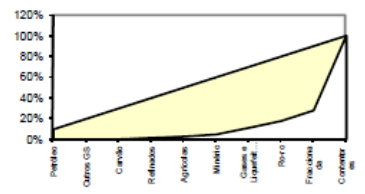

Fonte: Elaboração própria (a partir de freeware disponibilizado em):

http://people.hofstra.edu/geotrans/eng/gallery/Demo-Gini.xls 
ANEXO 3. Distribuição desagregada dos tipos de carga nos portos ibéricos (2010).

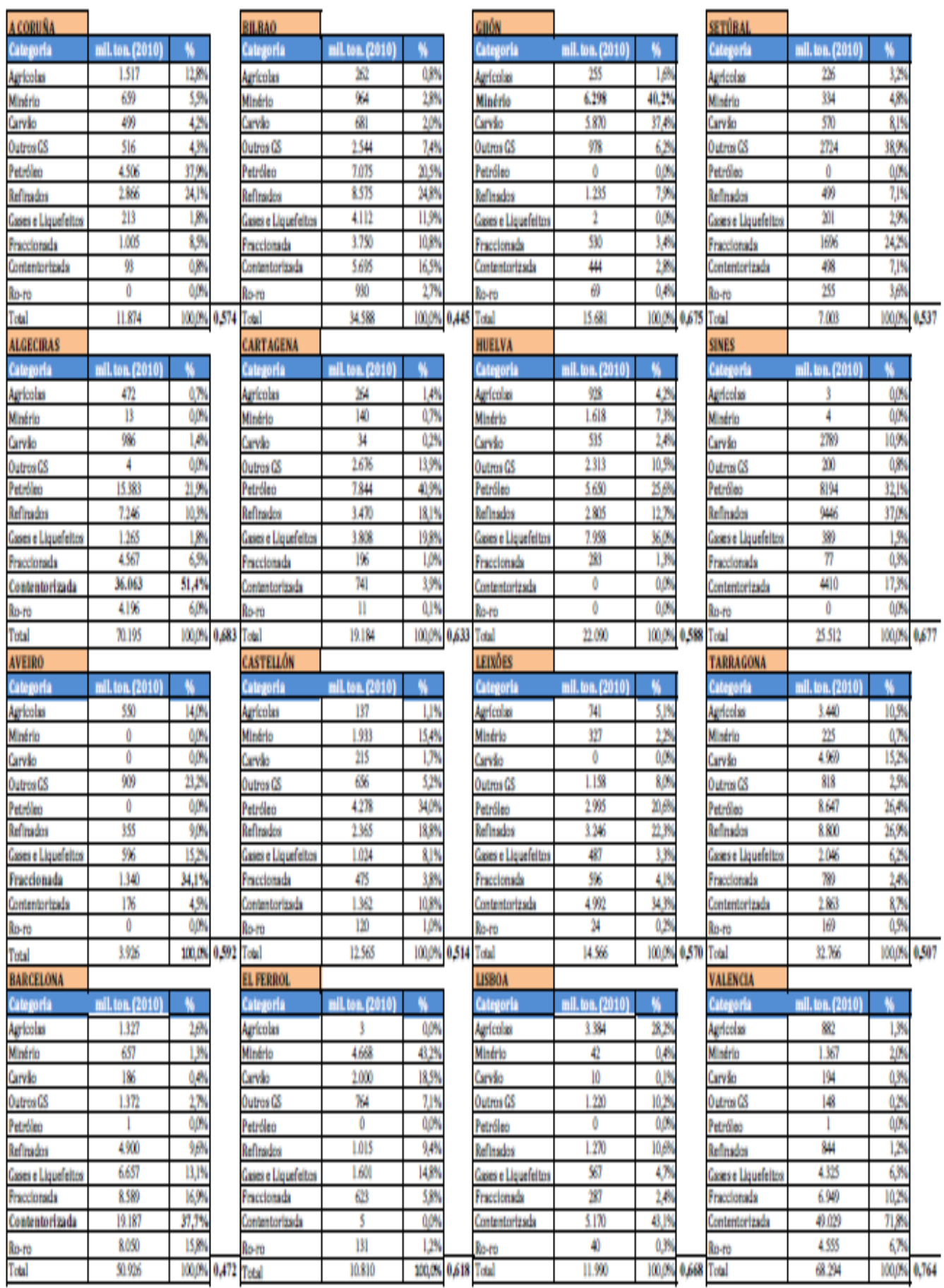

\begin{tabular}{|c|c|c|}
\hline TOTAIS & & \\
\hline Coteneith & 대. Ba RO101 & 4 \\
\hline Anficula & \begin{tabular}{|l|}
14391 \\
\end{tabular} & 39 \\
\hline Ylatefio & 10249 & $4 \pi$ \\
\hline Carkb & 10538 & $4 x$ \\
\hline 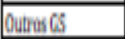 & 19000 & $46 \mathrm{k}$ \\
\hline \begin{tabular}{|l|} 
Petorilen \\
\end{tabular} & 64574 & $13 \pi$ \\
\hline Reffades & $\$ 8937$ & 143 \\
\hline 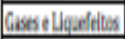 & 3325 & $86 \mathrm{~N}$ \\
\hline Frocdonata & 31.752 & $1, \pi$ \\
\hline Contentarisda & 13072 & $31, \pi$ \\
\hline Bo-10 & 18950 & 48 \\
\hline Tal & $411.9 \%$ & $100 \%$ \\
\hline
\end{tabular}

Fonte: Elaboração própria a partir de dados da APS e do portal Puertos del Estado. 
O Contributo de Sines na Eclosão de um Cluster Regional

ANEXO 4. Distribuição desagregada das cargas no porto de Sines (2002-2011).

\begin{tabular}{|c|c|c|c|c|c|c|c|c|c|c|}
\hline Sines & 2002 & 2003 & 2004 & 2005 & 2006 & 2007 & 2008 & 2009 & 2010 & 2011 \\
\hline & & mil ton. & mil ton. & mil ton. & mil ton. & mil ton. & mil ton. & mil ton. & mil ton. & mil ton. \\
\hline G.S. & 5.796 & 5.396 & 5.415 & 5.801 & 6.180 & 4.962 & 4.353 & 5.295 & 2.995 & 4.041 \\
\hline agrícolas & 4,2 & 5 & 2,5 & 6 & 0 & 2,4 & 2 & 3,6 & 3 & \\
\hline minérios & 66 & 6 & 4 & 12 & 4,3 & 8,7 & 0 & 4,2 & 3,5 & \\
\hline carvão & 5.668 & 5.330 & 5.234 & 5.255 & 5.737 & 4.621 & 3.956 & 4.967 & 2.789 & 3.902 \\
\hline outros & 57 & 54 & 174 & 526 & 438 & 330 & 395 & 320 & 200 & 135 \\
\hline G.L. & 14.318 & 15.442 & 16.764 & 18.551 & 19.506 & 19.321 & 17.780 & 15.977 & 18.030 & 16.150 \\
\hline petróleo & 8.736 & 9.457 & 9.883 & 10.046 & 9.913 & 9.009 & 8.651 & 7.159 & 8.194 & 7.029 \\
\hline refinados & 5.307 & 5.600 & 6.570 & 8.062 & 9.167 & 9.803 & 8.738 & 8.538 & 9.446 & 8.734 \\
\hline liquefeitos & 274 & 383 & 311 & 443 & 424 & 509 & 389 & 278 & 389 & 385 \\
\hline Fraccionada & 26 & 0 & 45 & 28 & 36 & 38 & 50 & 56 & 77 & 94 \\
\hline \begin{tabular}{|l|} 
Contentores \\
\end{tabular} & 0 & 24 & 250 & 658 & 1.473 & 1.977 & 2.964 & 3.050 & 4.410 & 5.050 \\
\hline Ro-ro & 0 & 0,55 & 0 & 0 & 0 & 0,02 & 0 & 0 & 0 & \\
\hline total & 20.141 & 20.863 & 22.474 & 25.041 & 27.196 & 26.299 & 25.148 & 24.379 & 25.513 & 25.335 \\
\hline
\end{tabular}

